\title{
Impacts of Nutrient Reduction on Coastal Communities
}

\author{
Catharina J. M. Philippart, ${ }^{1, *}$ Jan J. Beukema, ${ }^{1}$ Gerhard C. Cadée, ${ }^{1}$ \\ Rob Dekker, ${ }^{1}$ Paul W. Goedhart, ${ }^{2}$ Jolanda M. van Iperen, ${ }^{1}$ \\ Mardik F. Leopold, ${ }^{3}$ and Peter M. J. Herman ${ }^{4}$ \\ ${ }^{1}$ Department of Marine Ecology and Evolution, Royal Netherlands Institute for Sea Research, P.O. Box 59, 1790 AB Den Burg, \\ The Netherlands; ${ }^{2}$ Biometris, Wageningen University Research, P.O. Box 100, 6700 AC Wageningen, The Netherlands \\ ${ }^{3}$ Wageningen-IMARES, P.O. Box 167, 1790 AD Den Burg, The Netherlands; ${ }^{4}$ Centre of Estuarine and Coastal Ecology, \\ Netherlands Institute of Ecology, P.O. Box 140, 4400 AC Yerseke, The Netherlands
}

\begin{abstract}
Eutrophication due to high anthropogenic nutrient loading has greatly impacted ecological processes in marine coastal waters and, therefore, much effort has been put into reducing nitrogen and phosphorus discharges into European and NorthAmerican waters. Nutrient enrichment usually resulted in increase of biomass and production of phytoplankton and microphytobenthos, often coinciding with shifts in species composition within the primary producer community. Consequences of increasing eutrophication for higher trophic levels are still being disputed, and even less is known about the consequences of nutrient reduction on coastal food webs. Here, we present 30-year concurrent field observations on phytoplankton, macrozoobenthos and estuarine birds in the Dutch Wadden Sea, which has been subject to decades of nutrient enrichment and subsequent nutrient reduction. We demonstrate that long-term varia-
\end{abstract}

\section{INTRODUCTION}

Coastal eutrophication has become a wide-spread phenomenon during the past decades (Rosenberg

\footnotetext{
Electronic supplementary material The online version of this article (doi:10.1007/s10021-006-9006-7) contains supplementary material, which is available to authorized users.

published online 22 February 2007.

*Corresponding author; e-mail: katja@nioz.nl
}

tions in limiting nutrients (phosphate and silicon) were weakly correlated with biomass and more strongly with community structures of phytoplankton, macrozoobenthos and estuarine birds. Although we cannot conclusively determine if, and if so to what extent, nutrient enrichment and subsequent nutrient reduction actually contributed to the concurrent trends in these communities, it appears likely that part of the variance in the studied coastal communities is related to changes in nutrient loads. Our results imply that nutrient reduction measures should not ignore the potential consequences for policies aimed at bird conservation and exploitation of marine living resources.

Key words: Coastal marine ecosystems; eutrophication; nutrient reduction; phytoplankton; primary production; macrozoobenthos; estuarine birds; community structure; management. 
history traits such as growth curves and storage capacities (Grover 1997; Roelke and others 1999).

Previous analyses of long-term field observations in coastal waters revealed that changes in nitrogen and phosphorus concentrations were reflected in the total phytoplankton biomass, production and community structure (Bakker and others 1994; Philippart and others 2000), implying a strong causal relationship between the phytoplankton community structure and the availability of (limiting) nutrients. For example, principal component analysis of 20-year (1974-1994) high-resolution time series of the 32 most numerous marine algal species of the western Wadden Sea revealed that the phytoplankton community changed drastically between 1977 and 1978 and again between 1987 and 1988, and that it was relatively stable in-between and hereafter. These major changes in phytoplankton biomass and species composition coincided with changes in nutrient concentrations (Philippart and others 2000).

Eutrophic conditions are predicted to favor relatively large phytoplankton species that, due to their larger storage capacity, are better competitors under high and pulsing nutrient regimes (Sommer 1984; Stolte and others 1994; Grover 1997), whereas the biomass of smaller algae is primarily controlled by microzooplankton grazing (Thingstad and Sakshaug 1990; Riegman and others 1993). A system dominated by larger phytoplankton species is characterized by relatively large fluxes of carbon and nutrients to benthic communities via sedimentation of these large cells (Thingstad and Sakshaug 1990; Riegman and others 1993). In the western Wadden Sea, nutrient enrichment resulted in an increase in diatom biomass in general and an increase in larger cells in particular (Philippart and others 2000).

Phytoplankton and microphytobenthos are an important food source for macrozoobenthos (sediment-dwelling invertebrates $>1 \mathrm{~mm}$ ) in most shallow coastal seas. Living phytoplankton is sifted out of the water by filter-feeding bivalves at rates on the order of $1-10 \mathrm{~m}^{3} \mathrm{~m}^{-2} \mathrm{~d}^{-1}$ (Riisgaard and others 2004). Dead phytoplankton cells (detritus) as well as microphytobenthos are mostly eaten by deposit-feeding bivalves, gastropods and polychaetes (Beukema and others 2002). On the scale of estuaries, Herman and others (1999) showed that between 5 and $25 \%$ of the annual primary production is consumed by macrozoobenthos. Pathways of fluxes depend, however, on the trophic state of the estuary: high organic enrichment appears to favor filter feeders, whereas depositfeeding organisms predominate in areas with a low supply of organic matter (Pearson and Rosenberg 1987). It is, therefore, to be expected that longterm variation in primary production will be reflected in macrozoobenthic biomass, filtering capacity and community structure.

Macrozoobenthic communities generally support a suite of consumers, of which estuarine birds are amongst the most conspicuous. Bird numbers on a particular site depend not only on the conditions at that site, but also on conditions elsewhere in the species' distribution range (for example, Goss-Custard and others 1995). However, because the quality of a given estuary ("carrying capacity") for birds is determined by the local feeding conditions (GossCustard and others 2002), changes in these conditions will also affect local bird numbers (West and others 2005). Estuarine birds may be grouped into three main dietary categories, that is, those feeding on filter-feeding bivalves, on deposit- or mixedfeeding macrozoobenthos, or on other prey (Leopold and others 2004). Changes in macrozoobenthos biomass and species composition are, therefore, both expected to affect estuarine bird communities.

In this paper, we report possible consequences of changing nutrient conditions for phytoplankton, macrozoobenthos and estuarine birds, jointly comprising three trophic levels (that is, primary producers, primary consumers and secondary consumers). We use field data for the western Wadden Sea from the period for which consistent time series are available (1970-2003). Over the last 70 years, this area has been subject to an increase and subsequent decrease of phosphorus and nitrogen loads (van Raaphorst and de Jonge 2004). We examined the covariance in the long-term changes in dose (absolute and relative nutrient concentrations) and respective response in biomass, production and species composition of phytoplankton, macrozoobenthos and estuarine bird communities. The implications of our results for coastal system management are discussed.

\section{MethoDS}

\section{Study Area}

The Dutch Wadden Sea is a shallow, well-mixed tidal area that consists of several more or less separated tidal basins. Each basin comprises tidal flats, subtidal areas and channels. Basins are connected to the adjacent North Sea by relatively narrow and deep tidal inlets between the barrier islands. The two westernmost basins, Marsdiep and Vlie, have subtidal mussel culture plots. This part of the 
Wadden Sea has an area of $1,415 \mathrm{~km}^{2}$ and an average depth of $3.3 \mathrm{~m}$ (Ridderinkhof and others 1990).

The river Rhine is the main source of nutrients for this area. The densely populated drainage basin of this river comprises an area of $160,000 \mathrm{~km}^{2}$ upstream of the German-Dutch border and receives water from both snow melting in the Alps and rain. After passing the Dutch border, the Rhine splits into three branches. The first two branches flow (together with the river Meuse) westwards and drain into the North Sea, where the nutrients are transported northwards by means of the residual current along the Dutch coast, and subsequently enter the western Wadden Sea via the Marsdiep tidal inlet. The third branch flows northwards into Lake IJssel, a former part of the Wadden Sea that was closed off by a dike in 1932. Nowadays, Lake IJssel discharges its water into the western Wadden Sea through two sluices in the dike (van Raaphorst and de Jonge 2004).

\section{Nutrients}

Annual average riverine nutrient loads $\left(\mathrm{mol} \mathrm{s}^{-1}\right)$ into and concentrations $\left(\mathrm{mmol} \mathrm{m}^{-3}\right)$ within the western Wadden Sea were derived from the water quality monitoring database of the Dutch Ministry of Transport and Public Works. The database contains monthly averages of the concentrations of total (TP) and dissolved inorganic phosphorus (DIP), total nitrogen (TN), dissolved inorganic nitrogen (DIN $=$ ammonium, nitrite and nitrate), and dissolved inorganic silicon (DSi). Nutrient loads $\left(\mathrm{mol} \mathrm{s}^{-1}\right)$ from Lake IJssel into the Wadden Sea were calculated by multiplying the nutrient concentration $\left(\mathrm{mmol} \mathrm{m}^{-3}\right)$ within this freshwater lake at sampling station "Vrouwezand" near the freshwater discharge $\left(\mathrm{m}^{3} \mathrm{~s}^{-1}\right)$ through the Lake IJssel sluices into the western Wadden Sea. Previous analyses showed a strong correlation between the nutrient loads from this lake and nutrient concentrations in the Wadden Sea (Philippart and others 2000).

\section{Nutrient Limitation}

The identification of the most limiting nutrient for phytoplankton growth was based on nutrient concentrations of phosphorus, nitrogen and silicon. Because concentrations during the phytoplankton bloom do not accurately reflect relative biological availabilities (Howarth and Marino 2006), and (the commonly used) winter concentrations differ from those later in the year due to the relatively short residence time of the water ( 9 days, see Ridderinkhof and others 1990), we took the concentrations at the onset of the spring bloom. This onset was defined as the first date at which the daily increase in chlorophyll- $a$ concentrations exceeded $0.2 \mathrm{mg}$ Chl- $a \mathrm{~m}^{-3} \mathrm{~d}^{-1}$.

Two methods were used to identify the most limiting nutrient at the onset of the spring bloom. First, we calculated ratios of ambient nutrient concentrations ( $\mathrm{N}: \mathrm{P}$ and $\mathrm{N}: \mathrm{Si})$, and compared these values with Redfield ratios (nitrogen:phosphorus $=16: 1$ for all algae; nitrogen:silicon $=1: 1$ for diatoms). Deviations from the ambient ratio compared to the Redfield ratio indicate the nature and strength of the nutrient limitation. Second, we calculated the Monod-scaled concentrations of dissolved inorganic nutrients, $f_{\mathrm{DIN}}, f_{\mathrm{DIP}}$, and $f_{\mathrm{DSi}}$. For each nutrient (DIN, DIP and DSi), the scaled concentration is calculated according to $f_{X}=x /\left(x+x_{K}\right)$, where $x$ is the concentration $\left(\mathrm{mmol} \mathrm{m}^{-3}\right)$, and $x_{K}$ is the half-saturation coefficient $\left(2 \mathrm{mmol} \mathrm{m}^{-3}\right.$ for DIN and DSi, $0.2 \mathrm{mmol} \mathrm{m}^{-3}$ for DIP). Subsequently, the most limiting nutrient is defined as the one with the lowest $f_{X}$.

\section{Phytoplankton}

Phytoplankton species composition and chlorophyll- $a$ concentrations were determined from surface water samples, collected at a permanent sampling station in the western Wadden Sea at a sampling frequency from once a month in midwinter to twice a week during spring blooms.

Most algae were identified to species level; some were clustered into taxonomic and size groups (for example, small flagellates). For the present analysis, marine phytoplankton species were grouped into small (cell volume $<1,000 \mu \mathrm{m}^{3}$ ), intermediate-sized $\left(1,000 \mu^{3} \leq v \leq 10,000 \mu \mathrm{m}^{3}\right)$ and large $\left(v>10,000 \mu \mathrm{m}^{3}\right)$ diatoms and flagellates. Total plankton biomass (expressed as chlorophylla) was assessed from 0.5 to 11 water samples (see Cadée and Hegeman 2002 for methods).

Primary production was measured in an incubator, kept at in situ temperature and constant light conditions, using the ${ }^{14} \mathrm{C}$ method (Cadée and Hegeman 1974). In contrast to previous estimates of in situ primary production in this area, we now included actual daily irradiation in the estimation model (see Appendix A at http://www.springerlink.com).

\section{Calculation of Yearly Sums}

The nutrient and phytoplankton data came from different sources and were both irregularly sampled 
in time. Moreover, most variables exhibited very ragged behavior in time. In such cases the raw data could not be used to simply calculate yearly indices such as annual averages. Therefore, for each variable and separately for each year a regression model was fitted with time as the independent $(x)$ variable to calculate the yearly sums, which are the areas under the curves. Sums were not calculated for years that were only partly sampled. Phytoplankton cell counts were ${ }^{10} \log$-transformed before calculation of the yearly sums.

Because of the diversity in such fitted curves, smoothing splines (also known as generalized additive models), were used to model the annual time series (Hastie and Tibshirani 1990). Five degrees of freedom were used where possible. Ordinary regression, employing the normal distribution for error, was not appropriate for most variables, because the residual variations were not constant. In such cases, a generalized linear model (McCullagh and Nelder 1989) with a suitable distribution was used. We used the Poisson distribution with overdispersion for most nutrients and for chlorophyll- $a$, and the gamma distribution for primary production. The binomial distribution was used for variables that were by definition between 0 and 1 , that is, the Monod-scaled nutrient concentrations $\left(f_{x}\right)$.

\section{Macrozoobenthos}

In the western Wadden Sea, the macrozoobenthos is found on the tidal flats, in the subtidal areas and on subtidal culture plots (mussels only). Biomass and filter-feeding capacity of farmed mussels had to be back-calculated from commercial landings (Bult and others 2003), and should therefore be considered as indicative values only. Unfortunately, the time series of the macrozoobenthos in the remaining subtidal areas comprises only the second half of the study period and is therefore not taken into account.

For the intertidal macrozoobenthos, biomass density ( $\mathrm{g}$ ash-free dry mass $\mathrm{m}^{-2}$ ) and pumping capacity $\left(\mathrm{m}^{3} \mathrm{~m}^{-2} \mathrm{~h}^{-1}\right)$ of filter-feeding marine bivalves was determined from late-winter observations on mid-shore communities of the westermost tidal flats within the Wadden Sea (Stations 811 in Figure 1 of Beukema and others 2002). These stations were considered to be most representative of the average conditions in the western Wadden Sea. The main filter-feeding bivalves in this area are edible cockles (Cerastoderma edule), sandgapers (Mya arenaria) and blue mussels (Mytilus edulis). Total pumping capacity of these filter-feeding biv- alves was based upon species- and size-specific individual pumping rates, taking the submersion time and relative surface area of their specific habitat into account (Appendix B at http:// www.springerlink.com).

\section{Estuarine Birds}

Long time-series of bird numbers were based on synoptic bird counts at high-tide roosts, during 93 counts between September 1973 and May 2002 (data courtesy Dutch Centre for Field Ornithology SOVON). The counted roosts covered the entire Dutch Wadden Sea. Missing and poor quality values were replaced by fitted values by using the remaining available data, using site, year and month factors in a generalized linear model with a log-link function and a Poisson error distribution (Underhill and Prŷs-Jones 1994; van Roomen and others 2005). For each year and each bird species, the annual sum of the daily number of birds ("bird days") was calculated from July of the previous year to June.

Estuarine birds that eat large proportions of nonbenthic food (for example, terrestrial food or fisheries waste), birds that were clearly affected by other exogenous factors (such as fox predation), and birds for which few reliable counts were available were excluded from the analyses (Leopold and others 2004). Finally, the yearly sum of total bird biomass was calculated by summing up the annual number of bird days multiplied by the estimated average body mass for all species (Appendix C at http://www.springerlink.com).

\section{Trophic Periods}

Previous analysis of a 20-year (1974-1994) data set showed that both the nature of the limiting nutrient and the species composition of phytoplankton changed drastically between 1977 and 1978 and again between 1987 and 1988, and remained more or less stable during the periods between these shifts (Philippart and others 2000). To examine if these trophic periods still could be recognized in the longer data set of nutrients and phytoplankton, and if they were also detectable in data sets of macrozoobenthos and estuarine birds, we divided the time series into three periods, 1970-1977, 19781987, and 1988-2003. Although nutrient concentrations and phytoplankton concentrations mainly reflect the situation during spring, the macrozoobenthos and estuarine bird data were based on observations during the following winter. The trophic periods for macrozoobenthos and estuarine birds were, therefore, tested for differences 
between periodical means of 1970-1978, 19791988, and 1989-2003. During nutrient enrichment, the increase in macrozoobenthic biomass lagged 2-3 years behind the increase in phytoplankton biomass and production (Beukema and others 2002). For macrozoobenthos and estuarine birds, therefore, we additionally tested for differences between periodical means of 1970-1980, 1981-1990, and 1991-2003. Differences between periods were tested by means of general linear modelling, followed by Bonferroni-corrected pairwise comparisons.

\section{Dose-Response Relationships}

The relationships between the concurrent changes in nutrients and taxonomic groups were examined by correlation analyses of the time series, including time lags. Time lags from $-2^{1 / 2}$ to $+2^{1 / 2}$ years were applied when analyzing the correlation between the phytoplankton and macrozoobenthos time series, because measurements represent summer and winter values, respectively, and from -2 to +2 years for comparison of nutrients and phytoplankton and of macrozoobenthos and estuarine birds (measurements represent values at the same time of the year). Analyses were performed separately for changes in biomass (chlorophyll- $a$ of phytoplankton, ash-free dry weight of macrozoobenthos and fresh weight of estuarine birds), productivity (primary productivity of phytoplankton and filtering capacity of bivalves) and species composition (loadings of the principal components).

In the statistical contemplations of multiple comparisons, $P$-values are usually adjusted using the Bonferroni correction. However, arguments have recently been given not to adjust $P$-values in such comparisons, as this greatly reduces statistical power (Nakagawa 2004; Garamszegi 2006). We have therefore chosen to indicate significant correlations $(\mathrm{P}<0.05)$ between dose and response variables both with and without Bonferroni adjustment.

\section{RESUlTS}

\section{Nutrients}

Although annual loads of total phosphorus (TP) from Lake IJssel and concentrations of DIP (phosphate) in the western Wadden Sea at the start of the spring bloom were significantly correlated $\left(n=28, r^{2}=0.38, P<0.001\right)$, they showed different trends during the study period. Phosphorus loads gradually increased to maximum values in

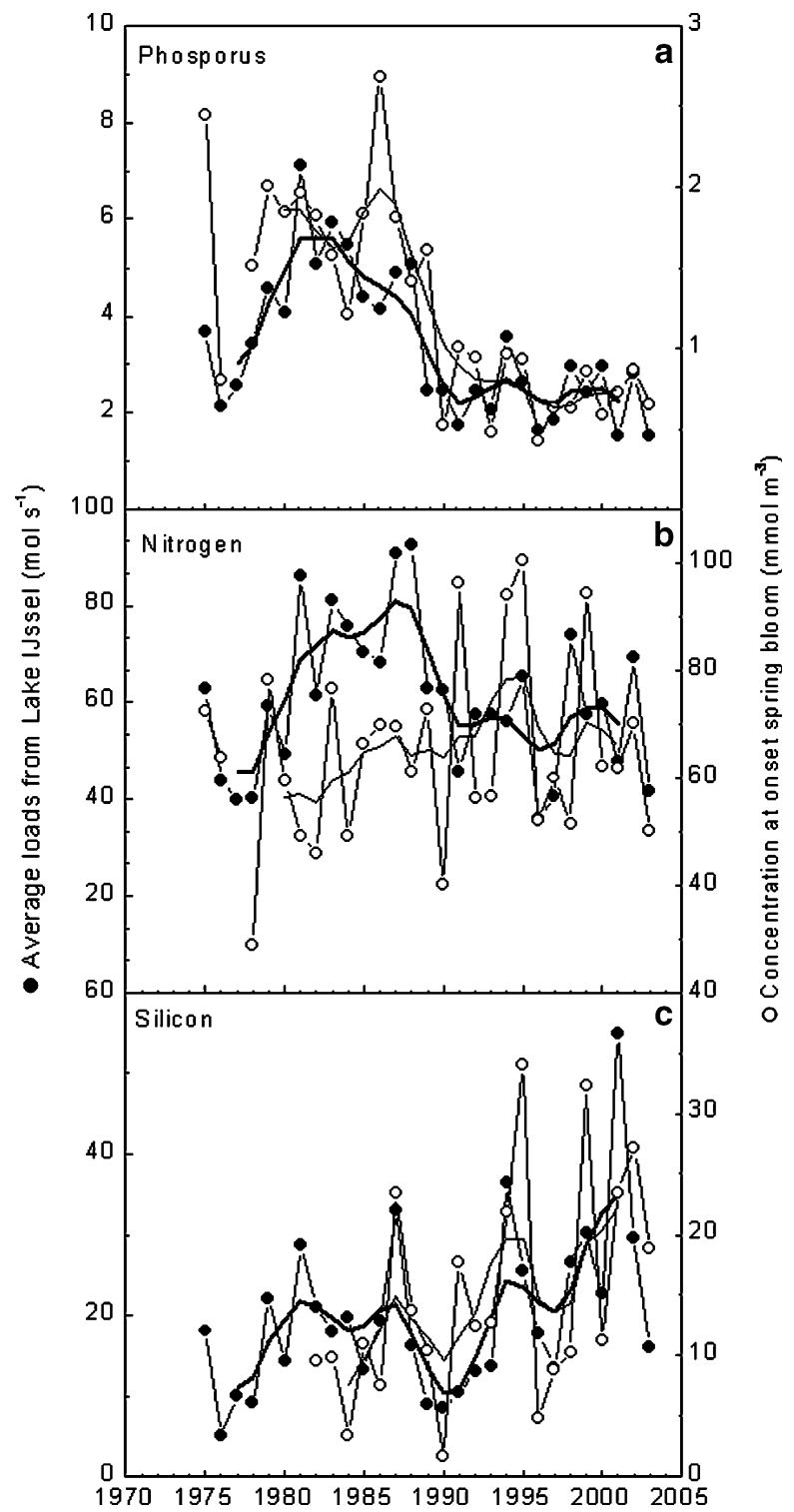

Figure 1. Time series of average nutrient loads from Lake IJssel (left axis; closed dots, thick smooth line depicts weighted running means of 5 years) during the year, and dissolved inorganic nutrient concentrations in the western Wadden Sea (right axis; open dots, thin smooth line depicts weighted running means) at the start of the spring bloom. a Total phosphorus loads (mol TP $\mathrm{s}^{-1}$ ) and dissolved inorganic phosphorus concentrations (mmol DIP $\left.\mathrm{m}^{-3}\right)$. b Total nitrogen loads $\left(\mathrm{mmol} \mathrm{TN} \mathrm{s}^{-1}\right)$ and dissolved inorganic concentrations $\left(\mathrm{mmol} \mathrm{DIN} \mathrm{m}^{-3}\right)$. c Dissolved inorganic silicon loads (mmol DSi s ${ }^{-1}$ ) and concentrations (mmol DSi $\mathrm{m}^{-3}$ ).

the early and mid-1980s, and subsequently decreased to previous levels during the 1990s. Phosphate concentrations were relatively high during the first two trophic periods, and significantly lower hereafter (Figure la, Table 1). For nitrogen, no significant relationship was found 
Table 1. Means and Standard Errors of Nutrient Loads $\left(\mathrm{mol} \mathrm{s}^{-1}\right)$, Concentrations $\left(\mathrm{mmol} \mathrm{m}^{-3}\right)$ and Scaled Concentrations (-) during Three Trophic Periods

\begin{tabular}{|c|c|c|c|c|c|c|c|c|}
\hline & 1970-1977 & & $1978-1987$ & & 1988-2003 & $n$ & $r^{2}$ & $P$ \\
\hline P-loads & $2.79 \pm 0.46^{\mathrm{a}}$ & S & $4.90 \pm 0.33^{b}$ & $S$ & $2.51 \pm 0.22^{\mathrm{a}}$ & 29 & 0.61 & 0.000 \\
\hline N-loads & $48.94 \pm 7.07^{\mathrm{a}}$ & & $68.27 \pm 5.09^{\mathrm{a}}$ & & $57.91 \pm 3.52^{\mathrm{a}}$ & 29 & 0.17 & 0.089 \\
\hline Si-loads & $11.06 \pm 3.81^{\mathrm{a}}$ & & $19.84 \pm 2.25^{\mathrm{a}}$ & & $21.52 \pm 3.05^{\mathrm{a}}$ & 29 & 0.09 & 0.284 \\
\hline [DIP] & $1.63 \pm 0.29^{a}$ & & $1.82 \pm 0.13^{\mathrm{a}}$ & $S$ & $0.83 \pm 0.10^{\mathrm{b}}$ & 28 & 0.60 & 0.000 \\
\hline [DIN] & $68 \pm 12^{a}$ & & $59 \pm 5^{a}$ & & $67 \pm 4^{\mathrm{a}}$ & 28 & 0.05 & 0.498 \\
\hline [DSi] & - & & $10.8 \pm 3.6^{\mathrm{a}}$ & & $16.3 \pm 2.2^{\mathrm{a}}$ & 22 & 0.08 & 0.201 \\
\hline$f_{\text {DIP }}$ & $0.86 \pm 0.06^{\mathrm{ab}}$ & & $0.88 \pm 0.01^{b}$ & $S$ & $0.76 \pm 0.02^{\mathrm{a}}$ & 28 & 0.58 & 0.000 \\
\hline$f_{\text {DIN }}$ & $0.96 \pm 0.00^{\mathrm{a}}$ & & $0.96 \pm 0.01^{\mathrm{a}}$ & & $0.96 \pm 0.00^{a}$ & 28 & 0.04 & 0.586 \\
\hline$f_{\mathrm{DSi}}$ & - & & $0.72^{a} \pm 0.07$ & & $0.79^{\mathrm{a}} \pm 0.03$ & 22 & 0.07 & 0.227 \\
\hline [DIN]:[DIP] & $55 \pm 14^{\mathrm{ab}}$ & & $33 \pm 6^{\mathrm{a}}$ & $S$ & $87 \pm 5^{b}$ & 28 & 0.64 & 0.000 \\
\hline [DSi]:[DIP] & - & & $6 \pm 4^{a}$ & $\mathrm{~S}$ & $20 \pm 2^{b}$ & & 0.33 & 0.005 \\
\hline
\end{tabular}

In each row, values with different superscripts $\left(^{a, b}\right)$ differ significantly.

$S$ significant shifts between periods.

between loads and concentrations $(n=28$, $\left.r^{2}=0.01, P=0.680\right)$, and neither loads nor concentrations of nitrogen significantly differed for the trophic periods (Table 1). For silicon, both loads $\left(n=29, r^{2}=0.19, P=0.018\right)$ and concentrations $\left(n=22, \quad r^{2}=0.22, \quad P=0.028\right) \quad$ significantly increased during (last two decades of) the study period (Figure 1c).

\section{Nutrient Limitation}

Based on the Redfield nutrient ratios, nutrient conditions for phytoplankton growth at the start of the spring bloom gradually shifted from the mid1970 s onwards from weak $\left(\mathrm{N}: \mathrm{P} \approx 16 \mathrm{~mol} \mathrm{~mol}^{-1}\right.$ ) to strong phosphorus-limitation (DIN:$\mathrm{DIP} \approx 100 \mathrm{~mol} \mathrm{~mol}{ }^{-1}$ ) (Figure $2 \mathrm{a}, \mathrm{b}$ ). For diatom growth, nutrient conditions at the start of the spring bloom gradually shifted from silicon-limitation in the 1980s onwards towards phosphoruslimitation in later years (Figure 2c, d). The DIN:DIP ratio was not significantly different between the first and second trophic period, whereas both the DIN:DIP and the DSi:DIP ratio were significantly higher during the third compared to the second trophic period (Table 1).

Based on the Monod-scaled concentrations of dissolved nutrients, $f_{\mathrm{DIN}}, f_{\mathrm{DIP}}$ and $f_{\mathrm{DSi}}$, DIN never limited phytoplankton growth at the start of the spring bloom (Figure 3a). Scaled DIP concentrations decreased between the second and third trophic period (Figure 3b, Table 1). For diatoms, silicon was most limiting during the second trophic period, but its scaled concentration significantly increased during the last two decades (Figure 3c; $\left.n=22, r^{2}=0.18, P=0.048\right)$. The combination of a decrease in DIP and an increase in DSi between the second and third trophic period resulted in DIP limitation for diatoms during the third trophic period (Table 1).

In summary, both measures for nutrient limitation indicate an overall enhancement of phosphorus limitation for phytoplankton growth in general, and a shift from silicon- to more phosphorus-limiting growth conditions for diatom growth in particular. The most apparent shifts in relative nutrient concentrations have occurred between the second and third trophic period.

\section{Phytoplankton}

Yearly sums of phytoplankton biomass more than doubled from the first to the second trophic period, and remained more or less constant hereafter (Table 2, Figure 4a). Based on a more restricted data set, it appeared that primary production may have simultaneously increased after the mid-1970s (Table 2, Figure $4 \mathrm{~b}$ ). In contrast to more or less stable chlorophyll concentrations during the 1980s and 1990s, primary productivity declined during the 1990s. Present average levels, however, are still higher than during the first trophic period (Table 2, Figure $4 \mathrm{~b}$ ). Both diatom and flagellate densities were higher during the second than during the first trophic period (Table 2). During the third trophic period, however, diatoms numbers were lower than during the second period, whereas flagellates further increased (Table 2).

Principal component analysis showed that the first two principal components (PCs) of the six phytoplankton groups accounted for 40 and $29 \%$ of the total variance of the standardized yearly sums of ${ }^{10} \log$-transformed cell densities (Figure 5). Covariability between phytoplankton groups was 


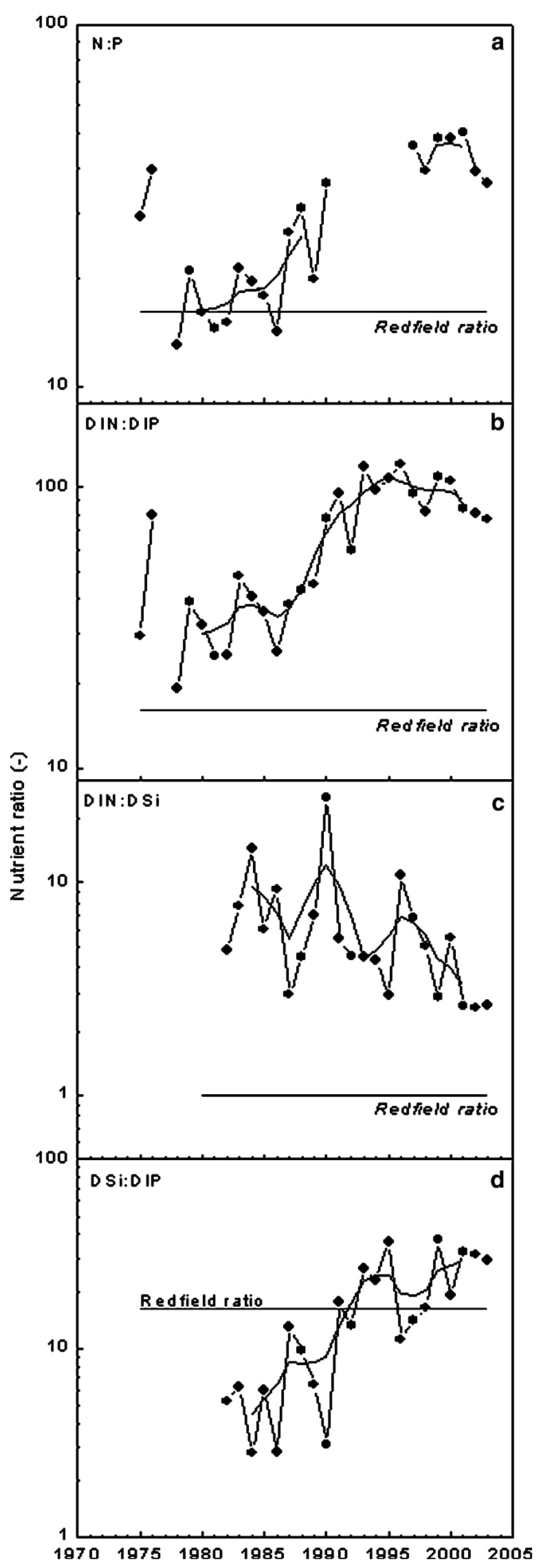

Figure 2. Time series of relative nutrient concentrations $\left(\mathrm{mol} \mathrm{mol}^{-1}\right)$ at the start of the spring bloom in the western Wadden Sea. a Ratio of total nitrogen and phosphorus (N:P). b Ratio of dissolved inorganic nitrogen and phosphorus (DIN:DIP). c Ratio of dissolved inorganic nitrogen and silicon (DIN:DSi). d Ratio of dissolved inorganic silicon and phosphorus (DSi:DIP). Thick smooth lines depict weighted running means, thin straight lines indicate Redfield ratios, $\mathrm{N}: \mathrm{P}=16, \mathrm{~N}: \mathrm{Si}=1, \mathrm{Si}: \mathrm{P}=16$.

relatively high considering that the first two PCs together explained $69 \%$ which is more than two times higher than when the time series of the six groups were not correlated at all (that is, 2/ $6 \times 100 \%=33 \%)$. The first component (PCl) showed an increase from the period 1974-1975 to the period 1978-2003 (Table 2, Figure 6a). Based on the correlations between the values of PCl and the underlying phytoplankton time series, this component reflected the changes in five out of six groups, that is, small diatoms $(r=0.73)$, intermediate-sized flagellates $(r=0.72)$, large diatoms $(r=0.70)$, small flagellates $(r=0.69)$ and intermediate-sized diatoms $(r=0.61)$. The second component (PC2) showed a significant decrease during the study period $\left(n=27, r^{2}=0.42\right.$, $P=0.000)$, in particular between 1987 and 1988 (Table 1, Figure 6b). This component mainly reflected the changes in large flagellates $(r=0.76)$ and intermediate-sized flagellates $(r=-0.63)$.

\section{Macrozoobenthos}

For both classifications of groups of trophic periods (with and without a time lag), the total biomass of intertidal macrozoobenthos almost doubled between the first and second trophic periods and remained more or less stable hereafter (Table 3, Figure $7 \mathrm{a}$ ). This increase was mainly due to the more than twofold increase in deposit- and mixedfeeding benthos (Table 3, Figure 7b). The summed biomass of the filter-feeding bivalves did not show significant differences between the trophic periods (Table 3, Figure 7c). The filter-feeding bivalves contributed differently to the year-to-year variation in biomass. Whereas the biomass of Mya arenaria, although strongly variable, showed an overall increase in time $\left(n=34, r^{2}=0.38\right.$, $P<0.001)$ resulting in higher values during the third than during the first trophic period (Table 3), the periodical means of Cerastoderma edule and $M y$ tilus edulis did not differ significantly (Figure 8, Table 3).

For the classification of trophic periods without a time lag, the overall filter-feeding capacity of 


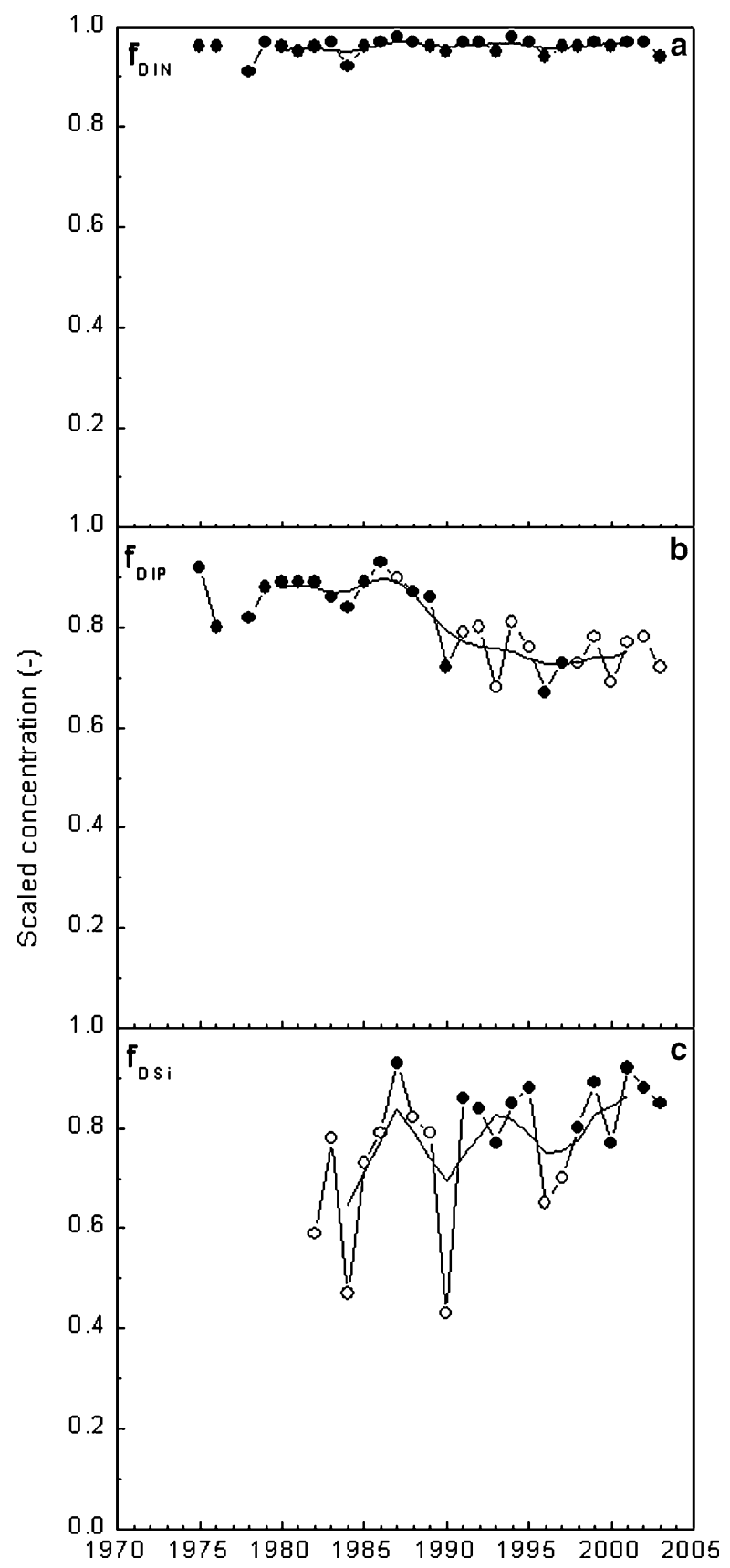

Figure 3. Monod-scaled nutrient concentrations (-) at the start of the spring bloom in the western Wadden Sea. a Dissolved inorganic nitrogen $\left(f_{\text {DIN }}\right)$. b Dissolved inorganic phosphorus $\left(f_{\text {DIP }}\right)$. c Dissolved inorganic silicon $\left(f_{\mathrm{DSi}}\right)$. Open dots indicate in which year the nutrient is limiting, based on the lowest value of $f_{\mathrm{DIN}}, f_{\mathrm{DIP}}$, and $f_{\mathrm{DSi}}$, respectively. Thick smooth lines depict weighted running means.

filter-feeding bivalves on the tidal flats decreased between the second and third trophic period (Table 3, Figure 9a). This decrease is no longer significant if a time lag of 3 years is considered (Table 3). As for biomass, filter-feeding capacity of
Mya arenaria increased, in particular between the first and second trophic period. Filtering capacity of intertidal cockles and mussels did not vary significantly between periods (Figure 8, Table 3), but their summed filtering capacity significantly decreased between the second and third trophic period from $142 \pm 27$ to $40 \pm 22 \mathrm{dm}^{3} \mathrm{~m}^{-2} \mathrm{~h}^{-1}$ $\left(n=34, r^{2}=0.27, \quad P=0.008\right)$. The filter-feeding capacity of the mussels on the culture plots was positively correlated with summed feeding capacity of the bivalves on the tidal flats $(n=31$, $r^{2}=0.11, P=0.031$ ), and significantly decreased between the second and the third trophic period (Figure 9b, Table 3).

The first two principal components of the PCA of the biomass density of dominant macrozoobenthic species $(n=8)$ accounted for 38 and $19 \%$ of the total variance of the standardized log-transformed biomass densities, which is more than two times higher $(57 \%)$ than when the time series of the eight macrozoobenthic species were not correlated at all (that is $2 / 8 \times 100 \%=25 \%$ ). The first component (PCl) showed an overall decrease during the study period $\left(n=34, r^{2}=0.71, \quad P=0.000\right.$; Figure 10a, Table 3), and mainly reflected the changes in the filter-feeding bivalves Mya arenaria $(r=-0.74)$, Cerastoderma edule $(r=0.41)$ and Mytilus edulis $(r=0.40)$, carnivorous polychaetes Nereis spp $(r=-0.70)$, and deposit-feeding polychaetes Heteromastus filiformis $(r=-0.66)$ and Arenicola marina $(r=-0.61)$. The second component (PC2) increased from the first to the second period and decreased again hereafter (Figure 10a, Table 3). This component mainly reflected the changes in the mainly deposit-feeding bivalve Macoma balthica $(r=0.82)$ and polychaete Arenicola marina $(r=0.69)$.

\section{Estuarine Birds}

The summed mass of estuarine birds did not change significantly during the study period (Figure 11, Table 4). On average, $56 \%$ of the total biomass was the summed biomass of the two bird species that mainly prey on filter-feeding bivalves (Figure 12a), and $44 \%$ of biomass originated from the 10 bird species that were feeding on deposit- and mixedfeeding benthos (Figure 12b). The summed mass of the two bird species that were feeding on other benthic prey comprised less than $1 \%$ (Figure 12c).

For both classifications of groups of trophic periods (with and without a time lag), the summed biomass of the birds preying on deposit- and mixed-feeding macrozoobenthos showed an increase between the second and third trophic period 
Table 2. Means and Standard Errors of Phytoplankton Biomass (yearly sum; mg Chl- $a \mathrm{~m}^{-3}$ ), Primary Production (yearly sum; $\mathrm{gC} \mathrm{m}^{-2} \mathrm{y}^{-1}$ ), Abundance of Diatoms and Flagellates (yearly sum; ${ }^{10} \log$-transformed cells $\mathrm{ml}^{-1}$ ) and Indices of Species Composition (principal components; -) at Three Trophic Periods

\begin{tabular}{|c|c|c|c|c|c|c|c|c|}
\hline & $1970-1977$ & & $1978-1987$ & & $1988-2003$ & $n$ & $r^{2}$ & $P$ \\
\hline Biomass & $1430 \pm 409^{a}$ & S & $3104 \pm 224^{b}$ & & $2902 \pm 177^{b}$ & 29 & 0.34 & 0.005 \\
\hline Production & $95.5 \pm 33.9^{\mathrm{a}}$ & $(\mathrm{S})$ & $(275.5)$ & $(\mathrm{S})$ & $184.6 \pm 12.8^{\mathrm{b}}$ & 16 & 0.30 & 0.028 \\
\hline Diatoms & $3625 \pm 240^{a}$ & $S$ & $4945 \pm 113^{c}$ & $S$ & $4356 \pm 85^{b}$ & 27 & 0.60 & 0.000 \\
\hline Flagellates & $3521 \pm 280^{\mathrm{a}}$ & $S$ & $5723 \pm 132^{b}$ & $S$ & $6334 \pm 99^{c}$ & 27 & 0.80 & 0.000 \\
\hline Species: PCl & $-2.78 \pm 0.42^{\mathrm{a}}$ & S & $0.51 \pm 0.20^{b}$ & & $0.06 \pm 0.15^{\mathrm{b}}$ & 27 & 0.68 & 0.000 \\
\hline Species: PC2 & $0.96 \pm 0.45^{\mathrm{a}}$ & & $0.93 \pm 0.21^{\mathrm{a}}$ & $S$ & $-0.64 \pm 0.16^{\mathrm{b}}$ & 27 & 0.62 & 0.000 \\
\hline
\end{tabular}

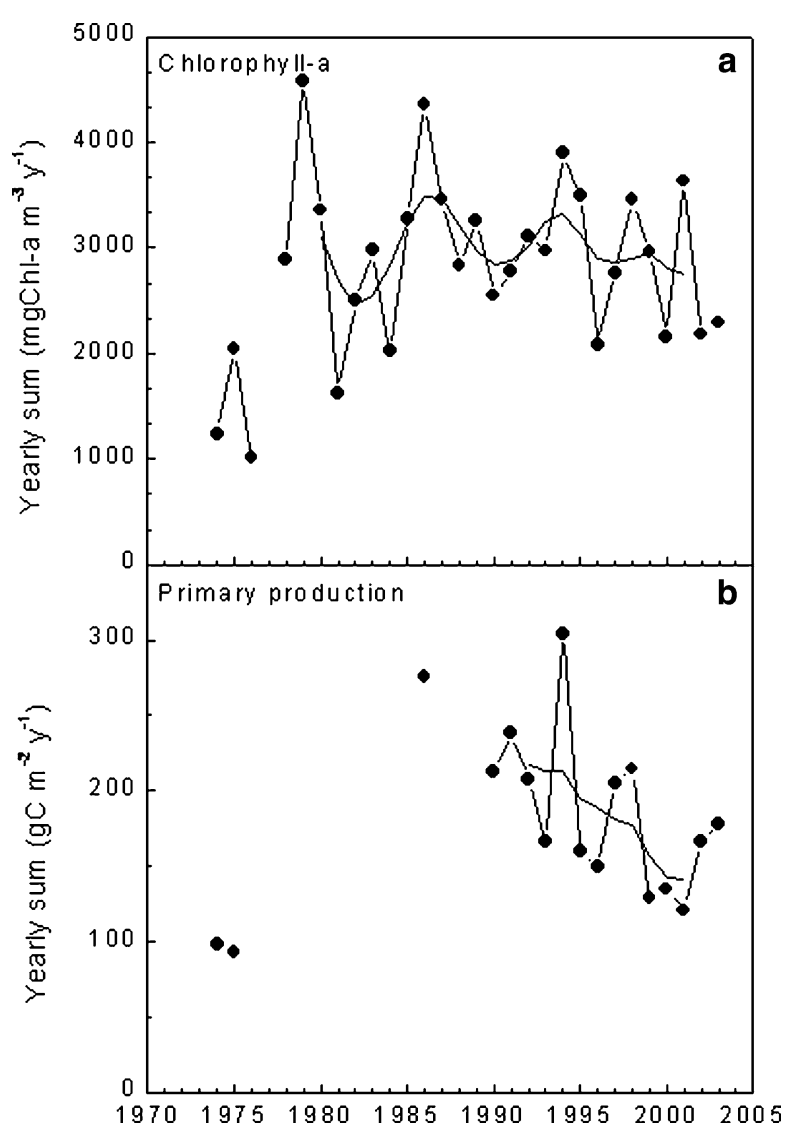

Figure 4. Time series of yearly sums (that is, area under annual curves) of a phytoplankton biomass (g Chl$\left.a \mathrm{~m}^{-3}\right)$, and $\mathbf{b}$ primary production $\left(\mathrm{g} \mathrm{C} \mathrm{m}^{-2} \mathrm{y}^{-1}\right)$ in the western Wadden Sea. Thick smooth lines depict weighted running means.

(Figure 12b, Table 4). The summed biomass of birds preying on filter-feeding bivalves showed no significant differences between periodical means (Figure 12a, Table 4). The summed biomass of the birds feeding on other prey generally increased over the entire study period (Figure 12c, Table 4).
The first two principal components (PCs) of the PCA of the abundance of estuarine bird species $(n=14)$ accounted for 34 and $15 \%$ of the total variance of the standardized log-transformed number of bird days (together explaining 49\%, which is more than three times higher than if the time series were not correlated at all, that is, 2/ $14 \times 100 \%=14 \%$ ). Values of the first component increased between the second and third trophic period (Figure 13a, Table 4). PC1 mainly reflected the changes in bar-tailed godwit $(r=0.83)$, grey plover $(r=0.80)$, sanderling $(r=-0.78)$, dunlin $(r=0.73)$, curlew $(r=0.68)$, ringed plover $(0.66)$, common greenshank $(r=0.65)$ and oystercatcher $(r=-0.56)$. Values of PC2 decreased significantly between the first and the second trophic period (Figure 13b, Table 4). PC2 mainly reflected the changes in common redshank $(r=0.91)$, ruddy turnstone $(r=0.66)$, spotted redshank $(r=-0.57)$ and dunlin $(r=0.50)$.

\section{Relationships Within Biomass, Productivity and Community Structure Characteristics}

Biomass. When probability was corrected for multiple comparisons, no significant relationship was found between the concentration of the limiting nutrients, DIP and DSi, at the start of the spring bloom and the yearly sum of phytoplankton biomass in that same year (Table 5). Without the correction, however, the phytoplankton biomass was positively related to the DIP concentrations at the onset of the spring bloom (Figure 14a). Biomass of deposit- and mixed-feeding macrozoobenthos was positively related to changes in phytoplankton biomass after $2^{1 / 2}$ years (Table 5, Figure 14b). No significant relationships were found between biomass of phytoplankton and that of the filter-feeding bivalves (Table 5). Without 

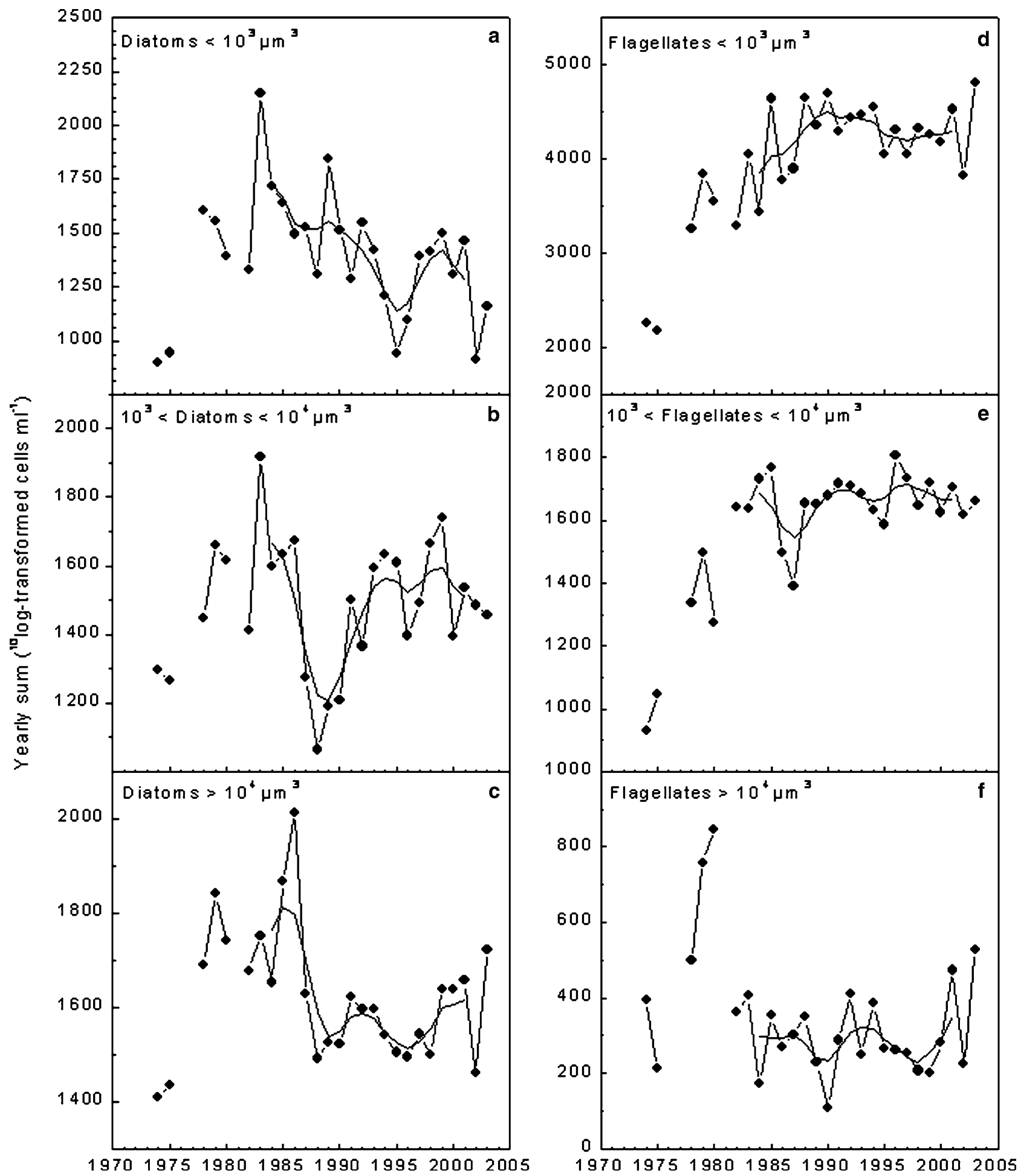

Figure 5. Time series of yearly sums (that is, area under annual curves) of ${ }^{10} \log$-transformed phytoplankton concentrations (cells $\mathrm{ml}^{-1}$ ) in the western Wadden Sea. a Small diatoms (cell volume $<1,000 \mu \mathrm{m}^{3}$ ). b Intermediate-sized diatoms $\left(1,000 \mu \mathrm{m}^{3} \leq\right.$ volume $\left.\leq 10,000 \mu \mathrm{m}^{3}\right)$. c Large diatoms (cell volume $\left.>10,000 \mu^{3}\right)$. d Small flagellates (cell volume $\left.<1,000 \mu \mathrm{m}^{3}\right)$. e Intermediate-sized flagellates $\left(1,000 \mu \mathrm{m}^{3} \leq\right.$ volume $\left.\leq 10,000 \mu \mathrm{m}^{3}\right)$. f Large flagellates (cell volume $>10,000 \mu \mathrm{m}^{3}$ ). Thick smooth lines depict weighted running means. 


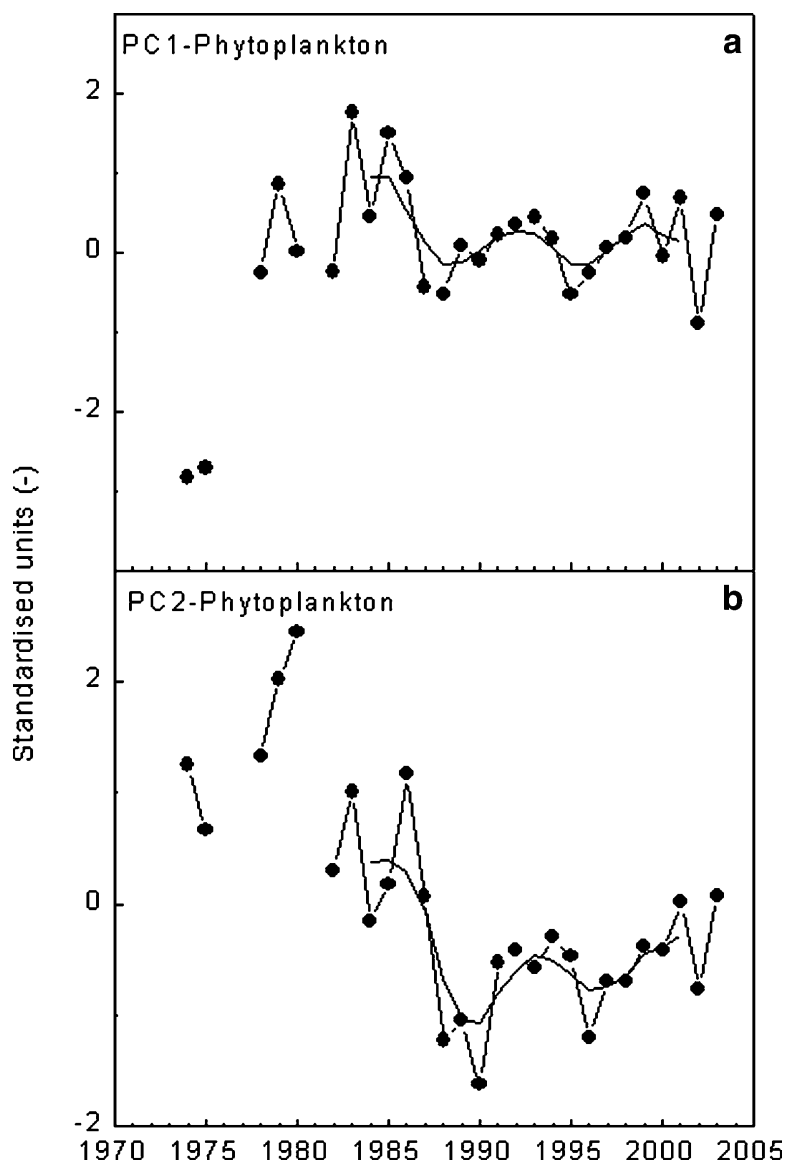

Figure 6. Scores of the first (a) and second (b) principal components (PCs) of the PCA of six phytoplankton groups (see Figure 5), which accounted for a respective 40 and $29 \%$ of the total variance of the standardized yearly sums of ${ }^{10} \mathrm{log}$-transformed cell densities. Thick smooth lines depict weighted running means.

correction for multiple comparisons, the biomass of the birds preying on filter-feeding bivalves was negatively correlated with that of the filter-feeding bivalves with a negative time lag of 1 year (Table 5, Figure 14c).

Productivity. Filter-feeding capacity of the bivalves on the tidal flats (Figure 15a) and on the mussel plots (Figure 15b) was weakly and negatively correlated with phytoplankton production with a negative time lag of $1 \frac{1 / 2}{2}$ and $1 / 2$ year, respectively (Table 6).

Community Structure. Various significant relationships were found between nutrients and community structures of phytoplankton, macrozoobenthos and estuarine birds as reflected in the first two principal components (Table 7). The positive relationship between DIP concentrations at the start of the spring bloom and PC2 of phytoplankton (Figure 16a) indicates that high phos- phate levels in early spring were mainly followed by high annual concentrations of large flagellates and, to a lesser extent, low cell densities of intermediate-sized flagellates. The (weak) negative relationship between DSi concentrations at the start of the spring bloom and PCl of phytoplankton (Figure 16d) indicates that high silicon levels were mainly followed by low overall abundance of phytoplankton cells, in particular diatoms.

The negative relationship between phytoplankton PCl and macrozoobenthic PCl with a time lag of $2 \frac{1}{2}$ years indicates that high overall abundance of phytoplankton cells was followed by high latewinter biomass of (mainly) Mya arenaria and Nereis spp. after two to 3 years (Table 7, Figure 16b). The positive relationships between phytoplankton PC2 and macrozoobenthos $\mathrm{PCl}$, with time lags ranging from $-2 \frac{1}{2}$ to $+1^{1 / 2}$ years, indicates that changes in macrozoobenthos were preceded by changes in the phytoplankton community (positive time lags) or were followed by changes in the phytoplankton community (negative time lags). The positive relationship between phytoplankton PC2 and macrozoobenthos PC 2 with a time lag of $+2^{1 / 2}$ years indicates that a decrease in large flagellates and, to a lesser extent, an increase in intermediate-sized flagellates was followed by a decrease in (mainly) Macoma balthica and Arenicola marina after two to 3 years (Figure 16e).

The positive relationship between PCl of macrozoobenthos and PC2 of estuarine birds indicates that winters with high biomass of (mainly) Mya arenaria and Nereis spp. were characterized by low numbers of (mainly) common redshank and ruddy turnstone (Table 7, Figure 16c). The negative relationship between PC2 of macrozoobenthos and $\mathrm{PCl}$ of estuarine birds suggests that winters with high biomass of (mainly) Macoma balthica and Arenicola marina were followed by low numbers of (mainly) bar-tailed godwit and grey plover 1 year later (Table 7, Figure 16e).

\section{Discussion}

\section{Nutrient Limitation}

Over the past two decades, a consensus has evolved within the scientific community that nitrogen is the primary cause of eutrophication in many coastal ecosystems around the world (Howarth and Marino 2006). However, our results from the various indices for nutrient limitation indicate that phosphorus was the main regulator of primary production in the western Wadden Sea for phytoplankton in general, whereas silicon has limited 
Table 3. Means and Standard Errors of Macrozoobenthos Biomass (Total, Deposit-mixed Feeders, and Filter-feeding Bivalves; gADW $\mathrm{m}^{-2}$ ), Pumping Capacity of Filter-feeding Bivalves (Cerastoderma edule, Mya arenaria, Mytilus edulis; $\mathrm{dm}^{3} \mathrm{~m}^{-2} \mathrm{~h}^{-1}$ ), and Indices of Species Composition (principal components, -) at Three Trophic Periods

\begin{tabular}{|c|c|c|c|c|c|c|c|c|}
\hline & $1970-1980$ & & $1981-1990$ & & 1991-2003 & $n$ & $r^{2}$ & $P$ \\
\hline Total biomass & $24.8 \pm 4.3^{\mathrm{a}}$ & $S$ & $42.0 \pm 4.1^{\mathrm{b}}$ & & $38.0 \pm 3.3^{\mathrm{ab}}$ & 34 & 0.23 & 0.017 \\
\hline FF bivalves & $19.0 \pm 4.2^{\mathrm{a}}$ & & $27.7 \pm 4.0^{\mathrm{a}}$ & & $23.2 \pm 3.2^{\mathrm{a}}$ & 34 & 0.07 & 0.330 \\
\hline C. edule & $9.2 \pm 2.8^{\mathrm{a}}$ & & $10.1 \pm 2.6^{\mathrm{a}}$ & & $3.2 \pm 2.2^{\mathrm{a}}$ & 34 & 0.14 & 0.093 \\
\hline M. arenaria & $6.6 \pm 3.1^{\mathrm{a}}$ & (S) & $15.7 \pm 2.9^{\mathrm{ab}}$ & $(\mathrm{S})$ & $19.6 \pm 2.4^{\mathrm{b}}$ & 34 & 0.27 & 0.008 \\
\hline M. edulis & $3.2 \pm 1.3^{\mathrm{a}}$ & & $1.9 \pm 1.2^{\mathrm{a}}$ & & $0.5 \pm 1.0^{\mathrm{a}}$ & 34 & 0.08 & 0.261 \\
\hline DM feeders & $5.6 \pm 0.5^{\mathrm{a}}$ & $S$ & $12.6 \pm 1.3^{\mathrm{b}}$ & & $11.8 \pm 0.8^{\mathrm{b}}$ & 34 & 0.48 & 0.000 \\
\hline Filtration & $149 \pm 29^{\mathrm{ab}}$ & & $176 \pm 28^{\mathrm{b}}$ & $S$ & $84 \pm 23^{a}$ & 34 & 0.19 & 0.037 \\
\hline C. edule & $112 \pm 28^{\mathrm{ab}}$ & & $123 \pm 26^{b}$ & $\mathrm{~S}$ & $35 \pm 21^{a}$ & 34 & 0.21 & 0.025 \\
\hline M. arenaria & $12 \pm 7^{a}$ & $(\mathrm{~S})$ & $34 \pm 6^{\mathrm{ab}}$ & $(\mathrm{S})$ & $44 \pm 5^{b}$ & 34 & 0.31 & 0.003 \\
\hline M. edulis & $25 \pm 9^{a}$ & & $18 \pm 9^{a}$ & & $5 \pm 7^{a}$ & 34 & 0.10 & 0.198 \\
\hline M. edulis* & $3814 \pm 234^{a}$ & & $3407 \pm 222^{a}$ & $S$ & $2000 \pm 202^{b}$ & 31 & 0.59 & 0.000 \\
\hline Species: PCl & $1.31 \pm 0.19^{\mathrm{a}}$ & S & $-0.10 \pm 0.18^{b}$ & $\mathrm{~S}$ & $-0.72 \pm 0.14^{\mathrm{c}}$ & 34 & 0.71 & 0.000 \\
\hline \multirow[t]{2}{*}{ Species: PC2 } & $-0.46 \pm 0.27^{\mathrm{a}}$ & $\mathrm{S}$ & $0.94 \pm 0.26^{b}$ & $S$ & $-0.35 \pm 0.21^{\mathrm{a}}$ & 34 & 0.38 & 0.001 \\
\hline & $1970-1980$ & & $1981-1990$ & & $1991-2003$ & $n$ & $r^{2}$ & $P$ \\
\hline Total biomass & $24.0 \pm 2.1^{\mathrm{a}}$ & $S$ & $44.3 \pm 4.2^{\mathrm{b}}$ & & $38.9 \pm 3.8^{\mathrm{b}}$ & 34 & 0.35 & 0.001 \\
\hline FF bivalves & $18.0 \pm 1.9^{\mathrm{a}}$ & & $27.4 \pm 5.0^{\mathrm{a}}$ & & $25.0 \pm 3.6^{\mathrm{a}}$ & 34 & 0.10 & 0.197 \\
\hline C. edule & $8.4 \pm 2.2^{\mathrm{a}}$ & & $10.0 \pm 4.1^{\mathrm{a}}$ & & $3.0 \pm 1.0^{\mathrm{a}}$ & 34 & 0.13 & 0.125 \\
\hline M. arenaria & $6.5 \pm 1.3^{a}$ & S & $15.9 \pm 2.1^{\mathrm{b}}$ & & $21.5 \pm 3.3^{b}$ & 34 & 0.38 & 0.001 \\
\hline M. edulis & $3.1 \pm 2.0^{\mathrm{a}}$ & & $1.5 \pm 0.5^{\mathrm{a}}$ & & $0.5 \pm 0.3^{\mathrm{a}}$ & 34 & 0.08 & 0.261 \\
\hline DM feeders & $5.8 \pm 0.5^{\mathrm{a}}$ & S & $14.9 \pm 0.9^{c}$ & $\mathrm{~S}$ & $10.9 \pm 0.6^{\mathrm{b}}$ & 34 & 0.72 & 0.000 \\
\hline Filtration & $146 \pm 22^{a}$ & & $164 \pm 43^{\mathrm{a}}$ & & $86 \pm 14^{a}$ & 34 & 0.13 & 0.108 \\
\hline C. edule & $108 \pm 24^{\mathrm{a}}$ & & $115 \pm 40^{\mathrm{a}}$ & & $33 \pm 10^{a}$ & 34 & 0.18 & 0.045 \\
\hline M. arenaria & $12 \pm 3^{a}$ & S & $35 \pm 5^{b}$ & & $48 \pm 7^{\mathrm{b}}$ & 34 & 0.41 & 0.000 \\
\hline M. edulis & $25 \pm 13^{a}$ & & $14 \pm 5^{a}$ & & $5 \pm 4^{\mathrm{a}}$ & 34 & 0.09 & 0.215 \\
\hline M. edulis* & $3824 \pm 232^{\mathrm{a}}$ & & $3050 \pm 282^{a}$ & $\mathrm{~S}$ & $1984 \pm 167^{\mathrm{b}}$ & 31 & 0.53 & 0.000 \\
\hline Species: PC1 & $1.25 \pm 0.13^{\mathrm{a}}$ & S & $-0.34 \pm 0.16^{\mathrm{b}}$ & & $-0.80 \pm 0.12^{\mathrm{b}}$ & 34 & 0.81 & 0.000 \\
\hline Species: PC2 & $-0.34 \pm 0.16^{\mathrm{a}}$ & S & $1.10 \pm 0.11^{\mathrm{b}}$ & $\mathrm{S}$ & $-0.56 \pm 0.27^{\mathrm{a}}$ & 34 & 0.53 & 0.000 \\
\hline
\end{tabular}

diatom growth during the first half of the study period. When using nutrient concentrations at the onset of the bloom as indices for their availability during the bloom, however, the relatively rapid and complete recycling of phosphorus compared to that of nitrogen is not taken into account. Although our results on relative nutrient concentrations indicated that phosphorus and silicon were mostly limiting phytoplankton growth, there remains still a possibility that nitrogen inputs may have ultimately driven the amount and scope of the primary production (for example, Dodds 2003).

Previous analyses of our long-term field observations revealed a positive relationship between the phytoplankton community structures in early spring and late summer (Philippart and others 2000), suggesting that spring conditions set the stage for the rest of the blooming period. Present correlation analyses of phytoplankton community structure and potentially limiting nutrients showed relationships between both DIP and DSi at the start of the spring bloom and phytoplankton species composition (Table 7). Noteworthy, the increase in DSi coincided with a decrease in diatoms (Table 7). This counterintuitive relationship may be the consequence of the strong phosphate limitation for phytoplankton growth, resulting in an inability for diatoms to use the silicon that is available. Furthermore, bioassays in the nearby open sea indicate P-limitation as well (Peeters and Peperzak 1990). These results strongly suggest that nitrogen was not the main limiting nutrient in our waters during the past 30 years.

\section{Phytoplankton}

Earlier publications showed that nutrient enrichment in the 1970s coincided with a steep increase 


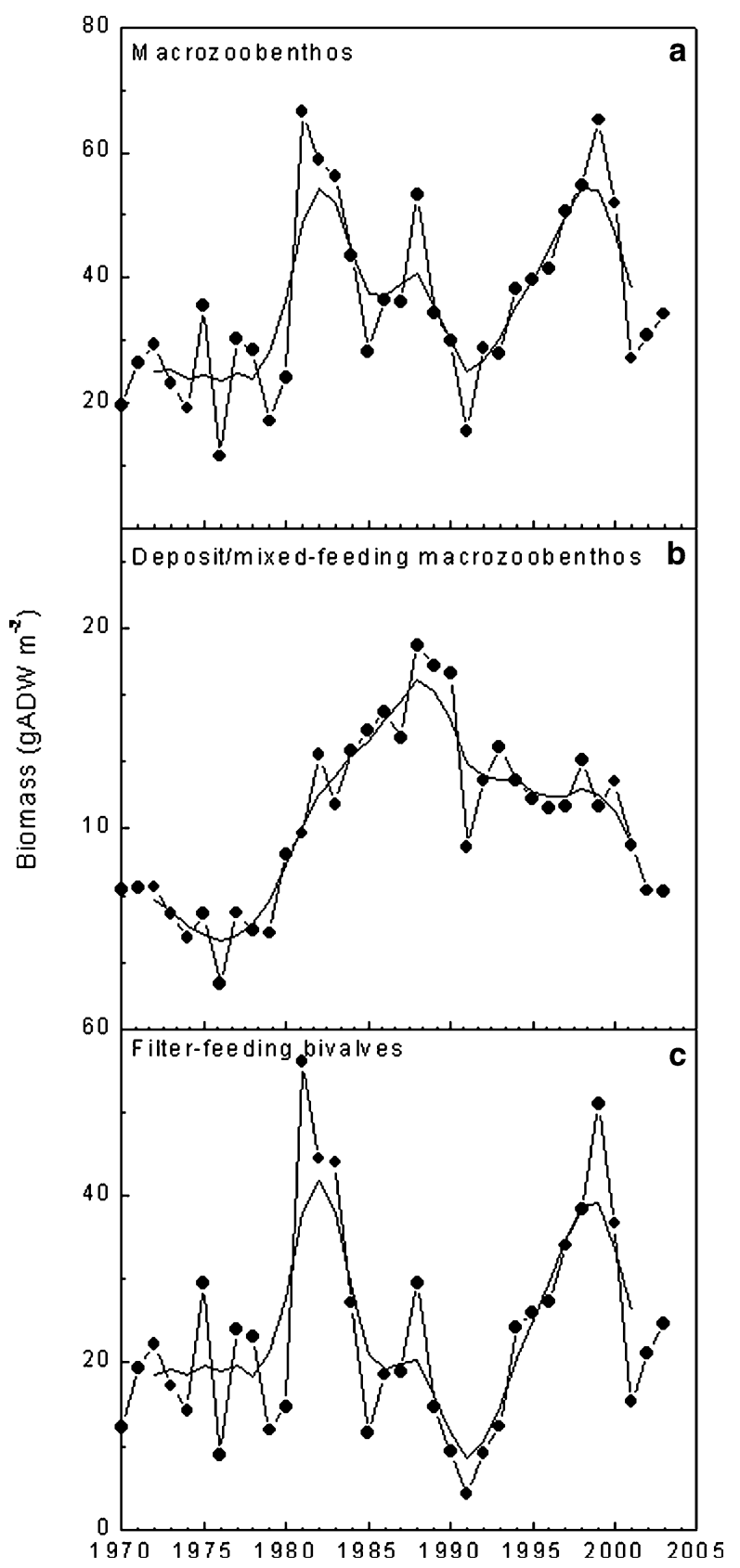

Figure 7. Time series of late-winter biomass of macrozoobenthos on tidal flats $\left(\mathrm{g} \mathrm{ADW} \mathrm{m}^{-2}\right)$ in the western Wadden Sea. a Summed biomass of eight dominant species. b Summed biomass of deposit- and mixed-feeding feeding macrozoobenthic species, Arenicola marina, Heteromastus filiformis, Lanice conchilega, and Macoma balthica c Summed biomass of filter-feeding bivalves, Cerastoderma edule, Mya arenaria and Mytilus edulis. Thick smooth lines depict weighted running means.

in biomass and production of both phytoplankton (Philippart and others 2000; Cadée and Hegeman 2002) and microphytobenthos (Cadée 1984). Subsequent nutrient reduction appears to have been

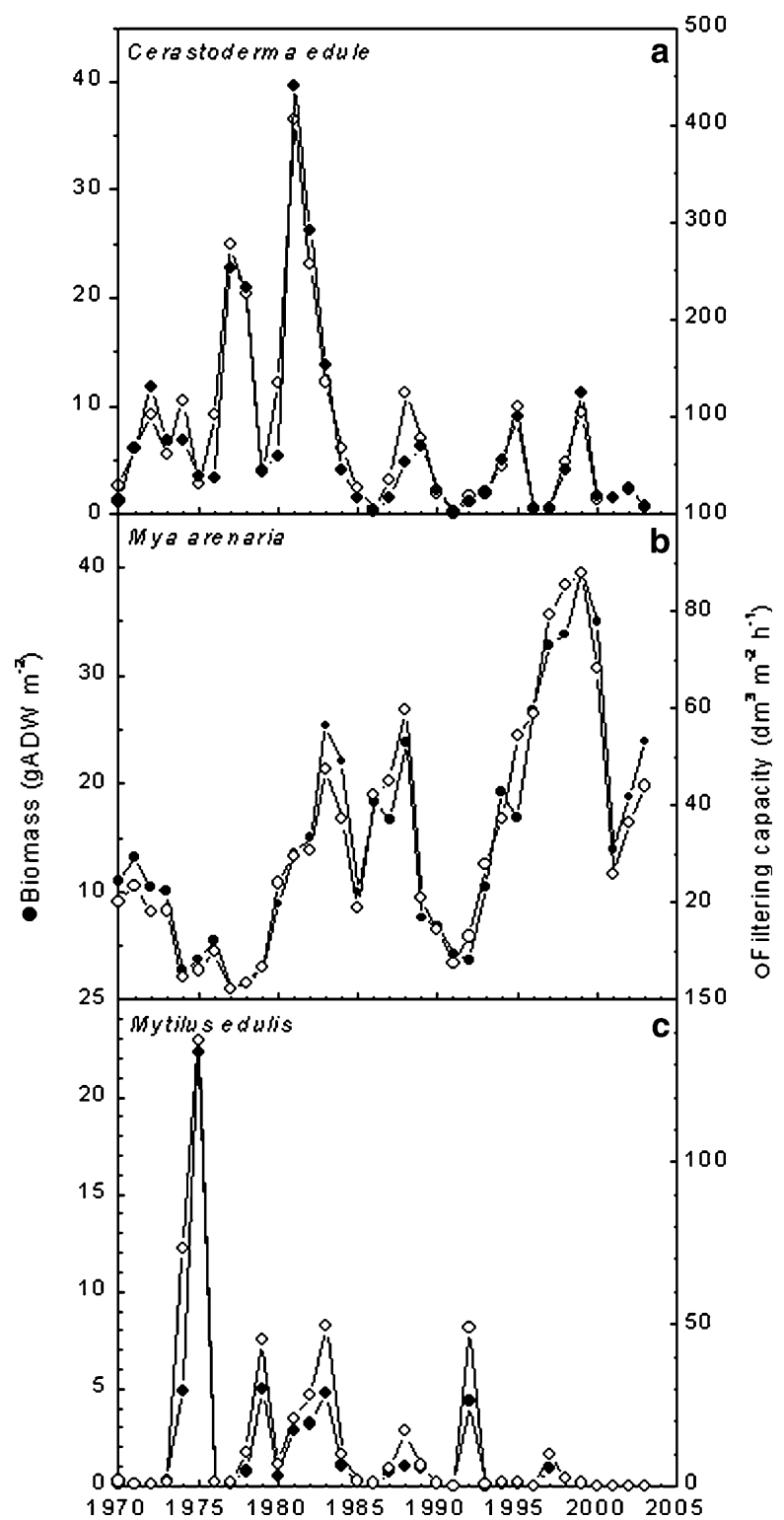

Figure 8. Time series of species-specific late-winter biomass (left axis; closed dots, g ADW $\mathrm{m}^{-2}$ ) and filter-feeding capacity (right axis; open dots, $\mathrm{dm}^{3} \mathrm{~m}^{-2} \mathrm{~h}^{-1}$ ) of filterfeeding bivalves a Cerastoderma edule, b Mya arenaria and c Mytilus edulis, at the tidal flats in the western Wadden Sea.

followed by a more gradual decrease in primary production of phytoplankton, although its biomass remained more or less constant (this paper), which implies that the P:B ratio of the phytoplankton was not constant over time. Regrettably, little information is available on microphytobenthos due to termination of this time series in the early 1980s (Cadée 1984).

Results of principal component analysis (Table 2, Figure 6) suggested that the phytoplankton com- 


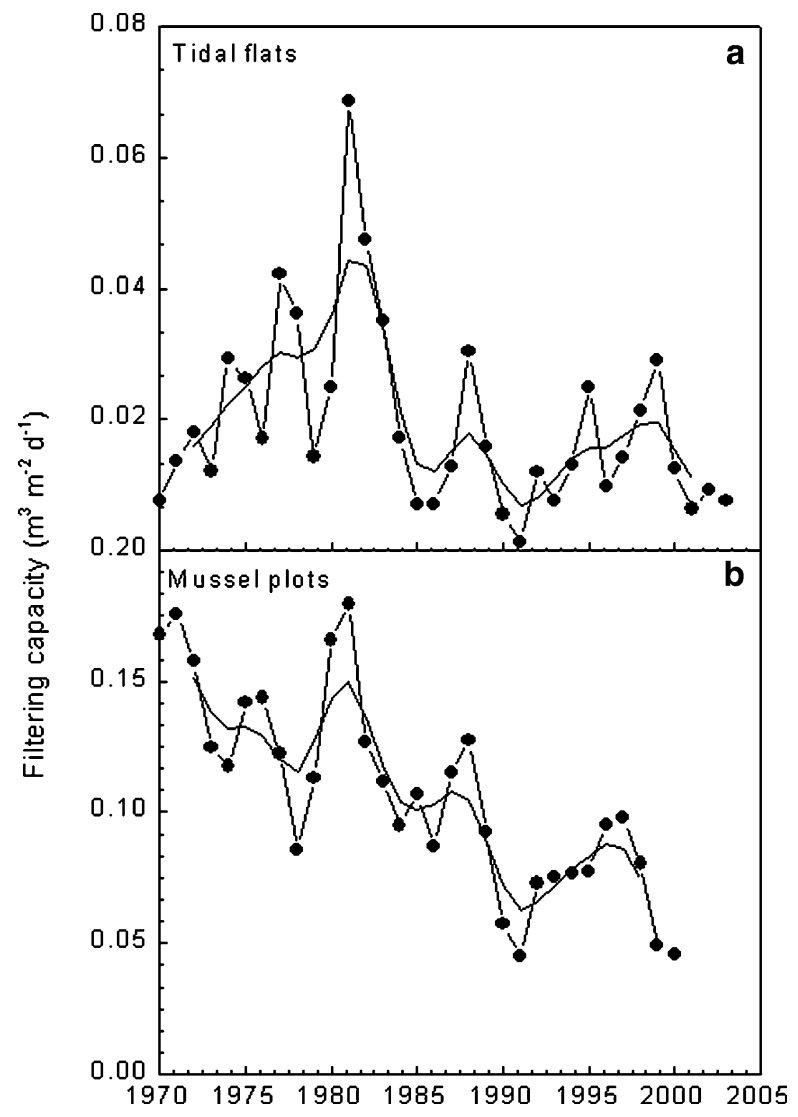

Figure 9. Time series of filtering-feeding capacity $\left(\mathrm{m}^{-3} \mathrm{~m}^{-2} \mathrm{~d}^{-1}\right)$ of a sum of three bivalve species, Cerastoderma edule, Mya arenaria and Mytilus edulis, on the tidal flats in the western Wadden Sea, and of $\mathbf{b}$ mussels, $M y$ tilus edulis, on the culture plots. Thick smooth lines depict weighted running means.

munity experienced two shifts in community structure, one between 1975 and 1978 (PC1) and one between 1987 and 1988 (PC2), possibly responses to nutrient enrichment and nutrient reduction, respectively. During the first shift, phytoplankton biomass and overall cell abundance increased for most groups, with exception of the large flagellates. During the second shift, however, overall phytoplankton biomass did not change, (smaller) flagellates further increased whereas diatom concentrations declined (Table 2). Although the first shift (as comprised in PC1) appears to be (weakly) related to DSi concentrations, the second shift in species composition (as comprised in PC2) was more strongly linked to variations in DIP concentrations at the start of the spring bloom (Table 7). However, it must be noted that primary productivity appeared to be linked with previous filtration capacity of filter-feeding bivalves on the tidal flats and the culture plots (Table 6), and that

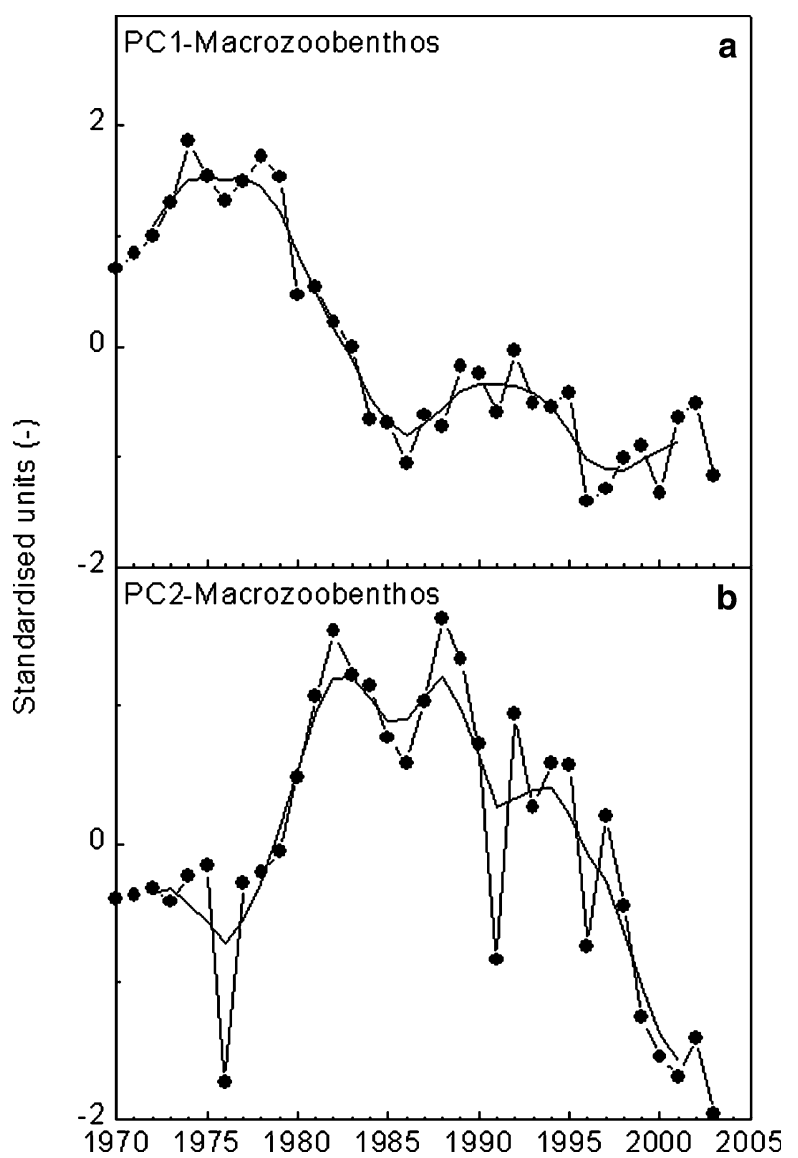

Figure 10. Scores of the first $(\mathbf{a})$ and second $(\mathbf{b})$ principal components $(P C S)$ of the PCA of eight dominant macrozoobenthos species, which accounted for a respective 38 and $19 \%$ of the total variance of the standardized biomass at late winter. Thick smooth lines depict weighted running means.

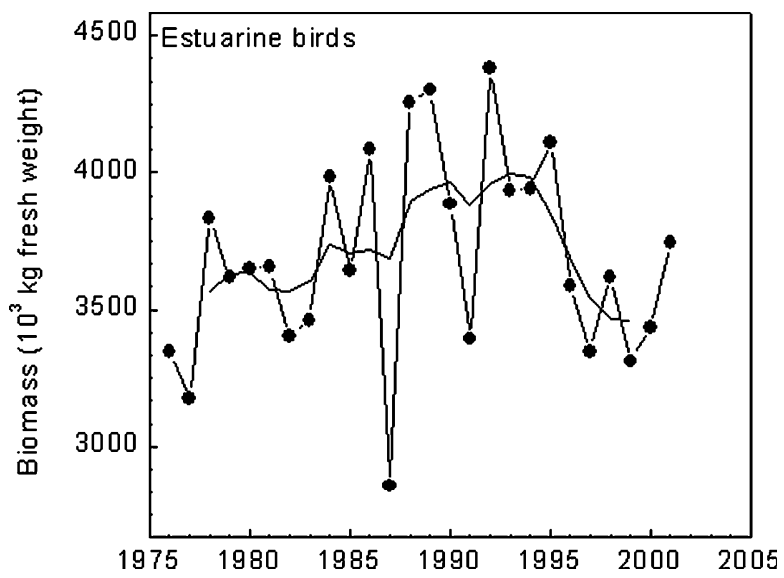

Figure 11. Time series of the yearly sum of daily total biomass $\left(10^{3} \mathrm{~kg}\right)$ of 14 species of estuarine birds in the Dutch Wadden Sea. Thick smooth line depicts weighted running mean. 
Table 4. Means and Standard Errors of Estuarine Bird Biomass (Total, Birds Preying on Deposit-mixed Feeding Macrozoobenthos and Filter-feeding Bivalves; $10^{3} \mathrm{~kg}$ fresh weight) and Species Composition (Principal Components; -) at Three Trophic Periods

\begin{tabular}{|c|c|c|c|c|c|c|c|c|}
\hline & $1970-1978$ & & $1979-1988$ & & 1989-2003 & $n$ & $r^{2}$ & $P$ \\
\hline Total biomass & $3450 \pm 215^{a}$ & & $3660 \pm 118^{a}$ & & $3768 \pm 103^{a}$ & 26 & 0.08 & 0.450 \\
\hline DMF prey & $1538 \pm 108^{\mathrm{ab}}$ & & $1424 \pm 59^{b}$ & S & $1767 \pm 52^{\mathrm{a}}$ & 26 & 0.46 & 0.001 \\
\hline FFB prey & $1907 \pm 181^{\mathrm{a}}$ & & $2231 \pm 99^{a}$ & & $1993 \pm 87^{\mathrm{a}}$ & 26 & 0.15 & 0.145 \\
\hline Other prey & $4.7 \pm 0.9^{\mathrm{a}}$ & (S) & $5.2 \pm 0.5^{\mathrm{ab}}$ & $(\mathrm{S})$ & $7.3 \pm 0.587^{b}$ & 26 & 0.35 & 0.007 \\
\hline Species: PC1 & $-0.44 \pm 0.42^{\mathrm{ab}}$ & & $-0.77 \pm 0.23^{\mathrm{a}}$ & S & $0.69 \pm 0.20^{b}$ & 26 & 0.51 & 0.000 \\
\hline \multirow[t]{2}{*}{ Species: PC2 } & $1.75 \pm 0.45^{\mathrm{a}}$ & S & $-0.05 \pm 0.25^{\mathrm{b}}$ & & $-0.37 \pm 0.22^{\mathrm{b}}$ & 26 & 0.44 & 0.001 \\
\hline & $1970-1980$ & & $1981-1990$ & & $1991-2003$ & $n$ & $r^{2}$ & $P$ \\
\hline Total biomass & $3523 \pm 117^{a}$ & & $3752 \pm 140^{\mathrm{a}}$ & & $3709 \pm 105^{a}$ & 26 & 0.05 & 0.536 \\
\hline DMF prey & $1477 \pm 49^{\mathrm{a}}$ & & $1476 \pm 55^{a}$ & S & $1790 \pm 70^{\mathrm{b}}$ & 26 & 0.42 & 0.002 \\
\hline FFB prey & $2042 \pm 136^{\mathrm{a}}$ & & $2271 \pm 96^{a}$ & & $1911 \pm 86^{\mathrm{a}}$ & 26 & 0.26 & 0.034 \\
\hline Other prey & $4.7 \pm 0.4^{\mathrm{a}}$ & & $5.3 \pm 0.4^{\mathrm{a}}$ & S & $7.7 \pm 0.6^{\mathrm{b}}$ & 26 & 0.46 & 0.001 \\
\hline Species: PCl & $-0.41 \pm 0.13^{\mathrm{a}}$ & & $-0.84 \pm 0.13^{\mathrm{a}}$ & S & $0.95 \pm 0.22^{\mathrm{b}}$ & 26 & 0.72 & 0.000 \\
\hline Species: PC2 & $1.50 \pm 0.28^{\mathrm{a}}$ & $\mathrm{S}$ & $-0.36 \pm 0.21^{\mathrm{b}}$ & & $-0.35 \pm 0.22^{\mathrm{b}}$ & 26 & 0.55 & 0.000 \\
\hline
\end{tabular}

changes in phytoplankton species composition were preceded by changes in the community structure of macrozoobenthos (Table 7). These results may indicate a (delayed) top-down control of filter-feeding bivalves on phytoplankton production and community structure, in addition to the possible bottom-up effects derived from changes in nutrient concentrations.

\section{Macrozoobenthos}

Periodic means of trophic periods (Table 3, Figure 6) and correlations between taxonomic groups (Table 7) indicated that the macrozoobenthos community experienced two periods of change during the last decades. The first shift at the end of the 1980s was characterized by an increase in biomass (predominantly as the result of an increase in deposit- and mixed-feeding benthos) and a change in species composition, whereas at the end of the 1980s only a shift in species composition was observed and biomass remained more or less stable.

Although the summed biomass of the filterfeeding bivalves did not significantly change, an overall increase of Mya arenaria was observed. With regard to filtering capacity, the increase in relatively slow filtering sandgapers could not compensate for the concurrent decrease in the joint filtering capacity of the more strongly filtering cockles and mussels, resulting in a decrease in the summed bivalve capacity between the second and third trophic period. This implies that, although no change in biomass was observed, the top-down control of the filter-feeding bivalves on the phytoplankton was lower during the third than during the second trophic period.

Changes in macrozoobenthos biomass of the deposit-mixed feeding benthos and species composition appear to be mostly lagging $2^{1 / 2}$ years behind changes in phytoplankton biomass and species composition (Tables 5, 7). This time lag may be the result of a delayed response of macrozoobenthos to changes in the phytoplankton, but possibly might also be an effect of changes in biomass and productivity of benthic microalgae due to phosphorus storage in the sediment and a subsequent delay in recycling.

The combination of the negative correlation and the negative time lag between biomass of birds that take filter-feeding bivalves and their prey (Table 5) indicates that high bird numbers were followed by low bivalve stocks 1 year later, and vice versa. This may imply that bird predation may play a role in determining the size of the bivalve stocks (topdown control). Subsequently the positive relationships between phytoplankton PC2 and macrozoobenthos $\mathrm{PC} 1$, with time lags ranging from $-2 \frac{1}{2}$ to $+1^{1 / 2}$ years may be a combined result of grazing of macrozoobenthos on the species composition of phytoplankton (top-down control) and of a response of the macrozoobenthos community to changes in the phytoplankton community (bottom-up control). 


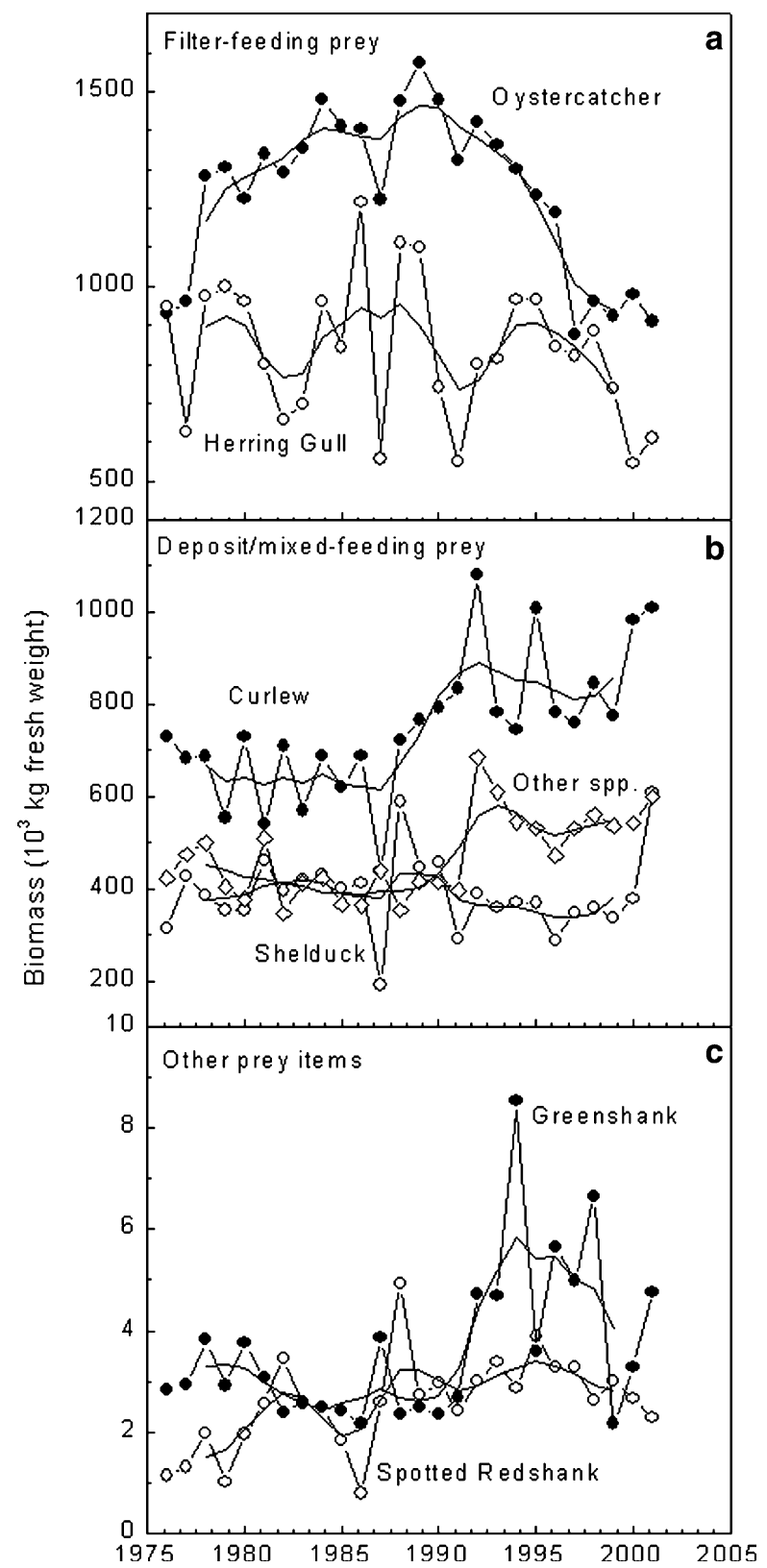

Figure 12. Time series of the yearly sum of daily total biomass $\left(10^{3} \mathrm{~kg}\right)$ of estuarine birds with different feeding guilds in the Dutch Wadden Sea. A Biomass of birds that prey on filter-feeding bivalves (oystercatcher and herring gull). B Biomass of birds that prey on deposit- and mixed-feeding macrozoobenthos species such as curlew and shelduck. C Biomass of birds that feed on other benthic prey items (greenshank and spotted redshank). Thick smooth lines depict weighted running means.

\section{Estuarine Birds}

Although the summed biomass of estuarine birds did not significantly change in time, periodic means of trophic periods indicated that this community still experienced two periods of change during the

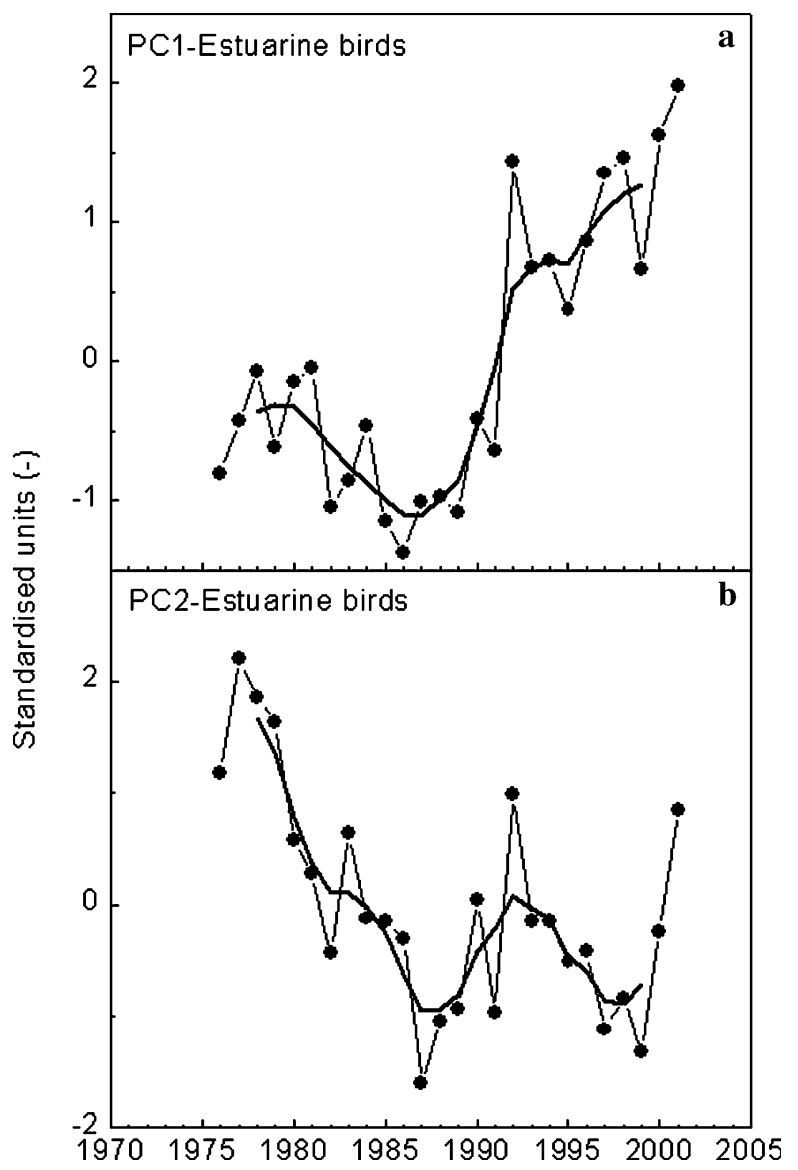

Figure 13. Scores of the first (a) and second (b) principal components $(P C s)$ of the PCA of estuarine bird species $(n=14)$, which accounted for a respective 34 and $15 \%$ of the total variance of the standardized yearly sums of daily total biomass. Thick smooth lines depict weighted running means.

last decades (Table 4). The summed biomass of estuarine birds feeding on deposit- and mixedfeeding macrozoobenthos increased between the second and third trophic period. Principal component analyses indicated a change between the first and second trophic period (PC2) and between the second and third trophic period (PC1), in particular if a time lag of $2 \frac{1}{2}$ years with regard to the trophic periods of phytoplankton is considered (Table 4).

There appears to be a strong and direct relationship between community structure of estuarine birds as reflected in PC2 and macrozoobenthos as reflected in PC1 (Table 7). In addition, changes in the estuarine bird community as reflected in PCl were related with some delay to changes in the macrozoobenthic community as reflected in PC2 (Table 7). One of the main changes within the macrozoobenthos was the increase in the proportion of Mya arenaria to the total macrozoobenthic 
Table 5. Pearson Correlation Coefficients of Relationships between Limiting Nutrients and Biomass Indices

\begin{tabular}{llllll}
\hline & \multicolumn{5}{l}{ Chlorophyll- $a\left(\mathrm{mg} \mathrm{m}^{-3}\right)$} \\
\cline { 2 - 5 } Nutrients & -2 & -1 & 0 & +1 & +2 \\
\hline DIP $\left(\mathrm{mmol} \mathrm{m}^{-3}\right)$ & -0.20 & -0.04 & 0.44 & 0.11 & -0.02 \\
DSi $\left(\mathrm{mmol} \mathrm{m}^{-3}\right)$ & 0.07 & 0.34 & 0.43 & -0.41 & -0.16 \\
\hline
\end{tabular}

\begin{tabular}{|c|c|c|c|c|c|c|c|c|c|c|c|c|}
\hline & \multicolumn{6}{|c|}{ Filter-feeding bivalves (gADW $\mathrm{m}^{-2}$ ) } & \multicolumn{6}{|c|}{ Deposit-mixed feeding benthos (gADW $\mathrm{m}^{-2}$ ) } \\
\hline & $-21 / 2$ & $-1 \frac{1 / 2}{2}$ & $-1 / 2$ & $+1 / 2$ & $+1 \frac{1}{2}$ & $+2 \frac{1}{2}$ & $-2 \frac{1 / 2}{2}$ & $-1^{1 / 2}$ & $-1 / 2$ & $+1 / 2$ & $+1 \frac{1 / 2}{2}$ & $+2 \frac{1}{2}$ \\
\hline Chl- $a\left(\mathrm{mg} \mathrm{m}^{-3}\right)$ & -0.23 & -0.20 & 0.03 & 0.13 & 0.34 & -0.15 & 0.24 & 0.30 & 0.34 & 0.37 & 0.50 & 0.52 \\
\hline
\end{tabular}

Birds preying on FF bivalves $\left(10^{3} \mathrm{~kg}\right)$

\begin{tabular}{|c|c|c|c|c|c|c|c|c|c|c|}
\hline \multirow[b]{2}{*}{ Zoobenthos } & & \\
\hline & -2 & -1 & 0 & +1 & +2 & -2 & -1 & 0 & +1 & +2 \\
\hline FFB $\left(\mathrm{gADW} \mathrm{m}^{-2}\right)$ & -0.13 & -0.45 & -0.37 & -0.36 & -0.24 & -0.04 & -0.13 & -0.05 & -0.09 & 0.04 \\
\hline $\mathrm{DM}\left(\mathrm{gADW} \mathrm{m}^{-2}\right)$ & 0.34 & 0.33 & 0.35 & 0.15 & 0.17 & -0.24 & -0.15 & 0.14 & -0.04 & 0.20 \\
\hline
\end{tabular}

Shown are the relationships between concentrations of dissolved inorganic nitrogen (DIN) and phosphorus (DIP) at the start of the spring bloom, yearly sums (Jan-Dec) of phytoplankton biomass and production, late winter biomass of filter-feeding bivalves and other macrozoobenthic species, and yearly sum (July-June) of biomass of estuarine birds preying on filter-feeding bivalves and on deposit-mixed feeding macrozoobenthic species. The time lag (in years) between the time series is indicated above the columns. Correlations that are significant without correction for multiple comparisons are italicized, and those that are still significant after Bonferroni-correction are printed in bold as well.

biomass from 27\% (1970-1980) via 36\% (1981$1990)$ to $55 \%(1991-2003)$. Because the adult clams burrow deeply, they are out of reach for most estuarine bird species (Zwarts and Wanink 1993). This implies that, although the total biomass of filter-feeding bivalves did not change significantly over time, the availability of these benthos species as a food source for birds may still have changed.

Previous analyses of long-term trends (19762002) of estuarine birds in the Wadden Sea showed that shellfish-preying birds were stable (for example, common eider Somateria mollissima) or increased (oystercatcher, herring gull and red knot) until the winter of 1990/1991, and declined in numbers hereafter (Leopold and others 2004). In contrast, five out of six birds that mainly prey on polychaetes increased during the study period (grey plover), since the winter of 1986/1987 (dunlin) or since the winter of 1990/1991 (ringed plover, bartailed godwit, sanderling). These results corroborate with present findings that the estuarine birds responded to the changes in abundance of their preferred benthic prey items.

\section{Different Responses to Nutrient Enrichment Compared to Nutrient Reduction}

In contrast to the sequential increase in biomass of phytoplankton and macrozoobenthos during nutrient enrichment at the end of the 1970s, subsequent nutrient reduction affected the biomass of these communities to a much lesser extent. The weak coupling between nutrient levels and biomass during the reduction phase might be a result of delayed response (for example, Jeppesen and others 1998) and concurrent changes in size structure, feeding modes or species composition (for example, Rossi and others 2004; Micheli and Halpern 2005) which can dampen the numerical and biomass responses at higher trophic levels.

For example, the different response may be the result of the shift in relative nutrient concentrations during nutrient reduction (which did not appear during nutrient enrichment, see Table 1), which may have enhanced shifts in phytoplankton and subsequently macrozoobenthos species composition. Furthermore, a shift from relatively small, short-living bivalves with high area-specific grazing rates (for example, mussels and cockles) towards relatively large long-lived ones with low area-specific grazing rates (for example, sandgapers) can result in a decline in overall pumping capacity (Fig. 8) and food demand of the filter-feeding bivalve community. If these bivalves are the main grazers in this system, the subsequent loss of grazing power can result in an increase (or the observed nonappearance of a decrease) in algal abundance, even during a period of nutrient reduction. In addition, shifts from surface-living to deeply burrowing 

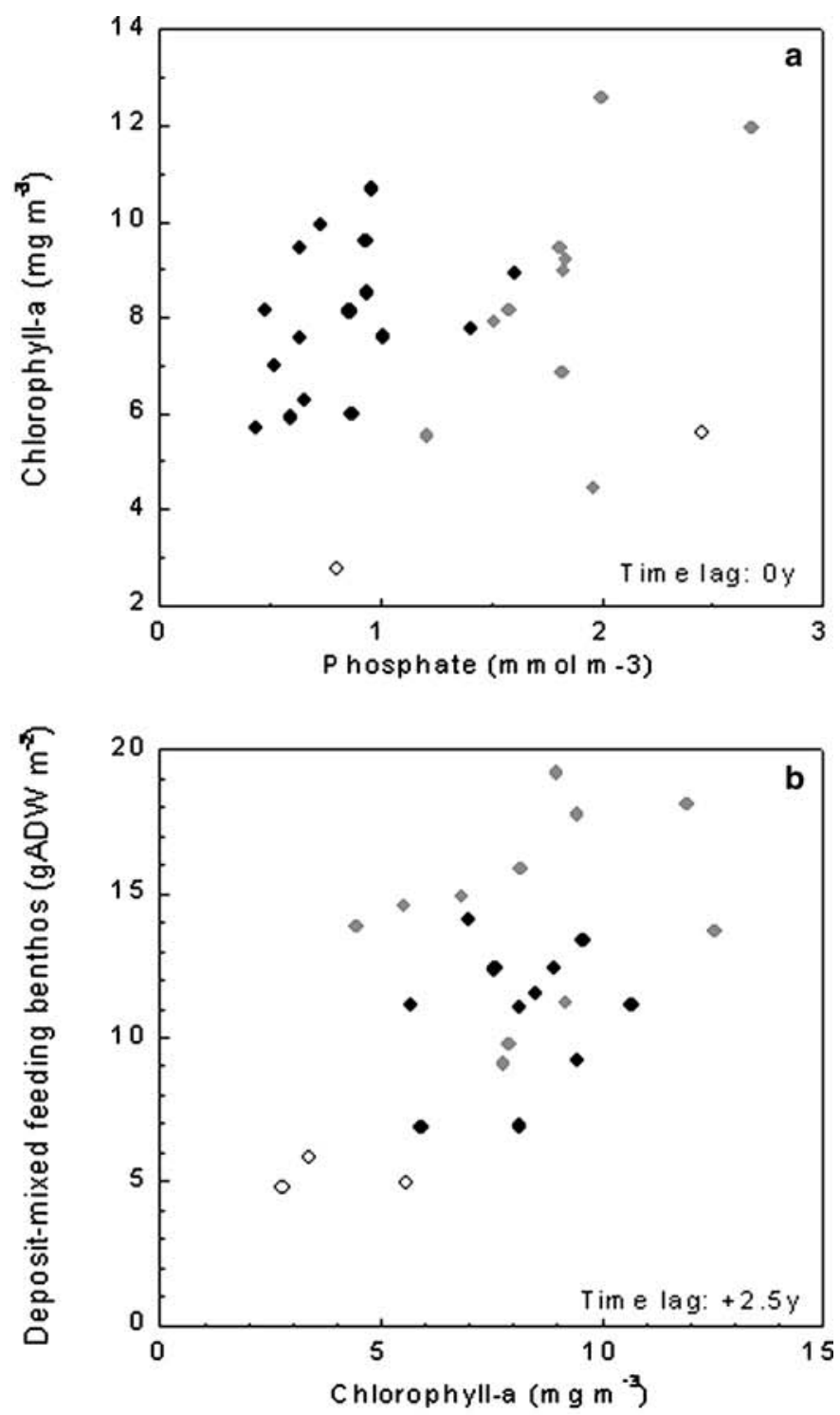

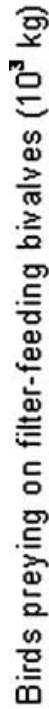

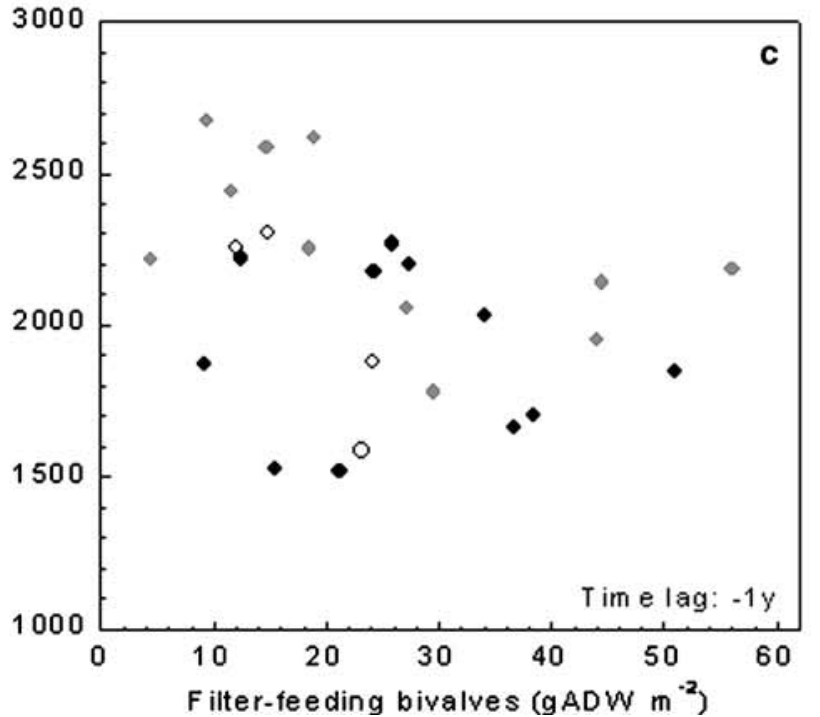

Figure 14. Relationships between limiting nutrients and indices of biomass. (a) Relationship between DIP concentration $\left(\mathrm{mmol} \mathrm{m}^{-3}\right)$ at onset of spring bloom and phytoplankton biomass (mg Chl- $a \mathrm{~m}^{-3}$ ). b Relationship between phytoplankton biomass (mg Chl- $a \mathrm{~m}^{-3}$ ) and biomass of deposit and mixed feeding macrozoobenthos $\left(\mathrm{gADW} \mathrm{m}^{-2}\right.$ ) after $2^{1 / 2}$ years. c Relationship between biomass of filter-feeding bivalves ( $\mathrm{gADW} \mathrm{m}^{-2}$ ) and biomass of estuarine birds preying on these bivalves $\left(10^{3} \mathrm{~kg}\right) 1$ year before. Open dots indicate first trophic period (1970-1977 for nutrients and phytoplankton, 1970-1980 for macrozoobenthos and birds), grey dots indicate second trophic period (1977-1987 and 19811990, respectively), and black dots indicate third trophic period (1988-2003 and 1991-2003, respectively). 

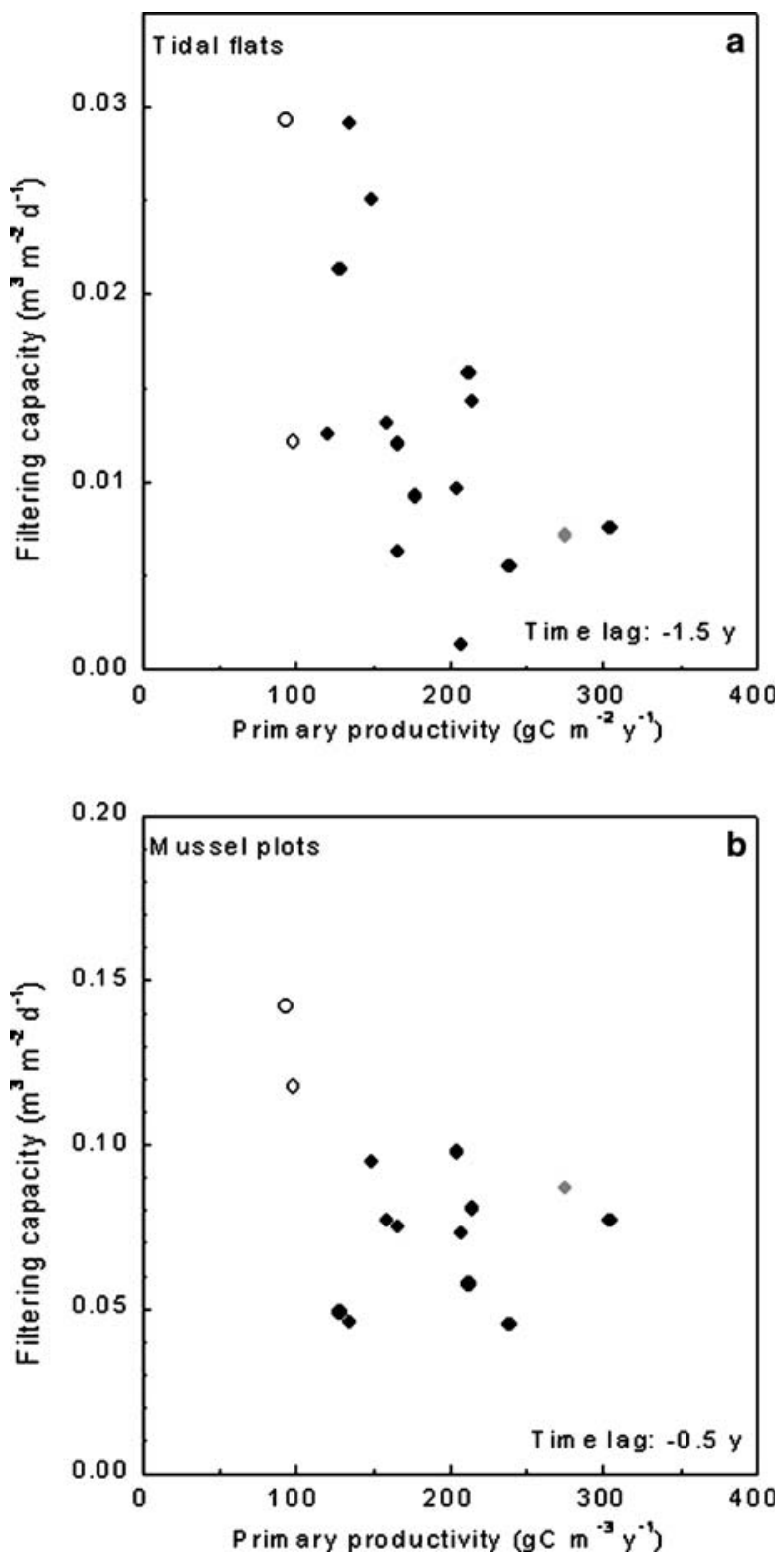

Figure 15. Relationships between limiting nutrients and indices of productivity. a Relationship between primary productivity of phytoplankton $\left(\mathrm{g} \mathrm{C} \mathrm{m}^{-3} \mathrm{y}^{-1}\right)$ and filtering capacity of the filter-feeding bivalves on the tidal flats $\left(\mathrm{m}^{3} \mathrm{~m}^{-2} \mathrm{~d}^{-1}\right)$. b Relationship between primary productivity of phytoplankton $\left(\mathrm{g} \mathrm{C} \mathrm{m}^{-3} \mathrm{y}^{-1}\right)$ and filtering capacity of mussels on culture plots $\left(\mathrm{m}^{3} \mathrm{~m}^{-2} \mathrm{~d}^{-1}\right)$. Open dots indicate first trophic period (1970-1977 for nutrients and phytoplankton, 1970-1980 for macrozoobenthos and birds), grey dots indicate second trophic period (1977-1987 and 1981-1990, respectively), and black dots indicate third trophic period (1988-2003 and 1991-2003, respectively).

benthic species may withdraw potential food from the estuarine bird communities, possibly dampening or enhancing the effects of changes in nutrient supply.

\section{Concurrent Factors}

In this study, we examined the covariance in the long-term changes in dose (absolute and relative nutrient concentrations) and respective response in biomass, production and species composition of phytoplankton, macrozoobenthos and estuarine bird communities. The actual explanatory value of the regression models must always be questioned, however, because the observed changes may be due to variations in other factors that were not included in the analysis, such as coinciding changes in shellfish fisheries, import of organic matter from the North Sea, recruitment success of bivalves and climate variability.

Shellfish Fisheries. Overexploitation of primary or tertiary consumers can cause similar effects as nutrient enrichment (Schindler 2006). In the early 1990s, an intense public discussion on shellfish exploitation in the Dutch Wadden Sea was fuelled by near destruction of intertidal mussel beds all over this area, unprecedented low bivalve stocks, and emigration and mass mortality of shellfish-eating birds (Beukema and Cadée 1996; Camphuysen and others 1996, 2002; Piersma and others 2001; Ens and others 2004). Shellfish fisheries became restricted by 1993, and the mechanical cockle fishery was closed in 2006. Because shellfish fisheries not only affected stocks but possibly also recruitment success (Piersma and others 2001), exploitation of shellfish may have contributed to the observed changes in cockles and mussels.

Import from the North Sea. In addition to riverine nutrient loads, primary production within the Wadden Sea is supported by nutrient release from remineralized organic matter that originates from the North Sea (Postma 1961; Philippart and others 2000; van Beusekom 2005). Among other factors, the strength of the exchange of matter between the North Sea and the Wadden Sea is determined by the tidal amplitude, which follows an 18.6 year cycle. During the study period, maximum values occurred in 1979 and 1998, and minimum value around 1987/1988 (Dronkers 2005). Nutrient enrichment originating from the river Rhine may, therefore, have been strengthened by a relatively high supply of nutrient-rich organic matter from the North Sea in the mid-1970s, whereas nutrient reduction may have been enforced due to relatively low imports of matter into the Wadden Sea at the end of the 1980s.

Recruitment Success. In north-western European estuaries, a series of mild winters followed by low bivalve recruit densities lead to small adult stocks, possibly as the result of a temperature-related 
Table 6. Pearson Correlation Coefficients of Relationships between Limiting Nutrients and Indices of Productivity

\begin{tabular}{|c|c|c|c|c|c|c|}
\hline \multirow[b]{2}{*}{ Nutrients } & \multicolumn{6}{|c|}{ Primary productivity $\left(\mathrm{g} \mathrm{C} \mathrm{m}^{-2} \mathrm{y}^{-1}\right)$} \\
\hline & \multicolumn{2}{|r|}{-2} & -1 & 0 & +1 & +2 \\
\hline DIP $\left(\mathrm{mmol} \mathrm{m}{ }^{-3}\right)$ & \multicolumn{2}{|r|}{-0.40} & 0.49 & 0.37 & -0.50 & 0.23 \\
\hline \multirow[t]{2}{*}{ DSi $\left(\mathrm{mmol} \mathrm{m}^{-3}\right)$} & & -0.40 & 0.51 & -0.15 & -0.35 & -0.15 \\
\hline & \multicolumn{3}{|c|}{ Tidal flats $\left(\mathrm{m}^{3} \mathrm{~m}^{-2} \mathrm{~d}^{-1}\right)$} & & & \\
\hline Plankton & $-2 \frac{1}{2}$ & $-1 \frac{1}{2}$ & $-1 / 2$ & $+1 / 2$ & $+1 \frac{1 / 2}{2}$ & $+2 \frac{1}{2}$ \\
\hline \multirow[t]{2}{*}{ Prim Prod $\left(\mathrm{gC} \mathrm{m}^{-2} \mathrm{y}^{-1}\right)$} & 0.06 & -0.69 & -0.62 & 0.07 & -0.22 & -0.49 \\
\hline & \multicolumn{3}{|c|}{ Mussel plots $\left(\mathrm{m}^{3} \mathrm{~m}^{-2} \mathrm{~d}^{-1}\right)$} & & & \\
\hline Plankton & $-21 / 2$ & $-11 / 2$ & $-1 / 2$ & $+1 / 2$ & $+1^{1 / 2}$ & $+2 \frac{1}{1} 2$ \\
\hline Prim Prod $\left(g C \mathrm{~m}^{-2} \mathrm{y}^{-1}\right)$ & -0.40 & -0.43 & -0.65 & -0.58 & -0.31 & -0.09 \\
\hline
\end{tabular}

Shown are primary production of phytoplankton $\left(\mathrm{g} C \mathrm{~m}^{-2} y^{-1}\right)$ and filtering capacity of bivalves on the tidal flats and in the mussel plots $\left(\mathrm{m}^{3} \mathrm{~m}^{-2} \mathrm{~d}^{-1}\right)$. The time lag (in years) between the time series is indicated above the columns. Significant correlations are italicized (without correction for multiple comparisons) and printed in bold (if still significant after Bonferroni-correction).

Table 7. Pearson Correlation Coefficients of Relationships between Limiting Nutrients and Indices of Community Structure

\begin{tabular}{|c|c|c|c|c|c|c|c|c|c|c|}
\hline \multirow[b]{2}{*}{ Nutrients } & \multicolumn{5}{|c|}{ Phytoplankton (PCl) } & \multicolumn{5}{|c|}{ Phytoplankton (PC2) } \\
\hline & -2 & -1 & 0 & +1 & +2 & -2 & -1 & 0 & +1 & +2 \\
\hline DIP & 0.49 & 0.46 & 0.32 & -0.15 & -0.22 & 0.55 & 0.45 & 0.65 & 0.15 & -0.23 \\
\hline DSi & 0.35 & -0.10 & -0.10 & -0.53 & 0.06 & -0.05 & 0.03 & 0.22 & -0.32 & -0.14 \\
\hline
\end{tabular}

\begin{tabular}{|c|c|c|c|c|c|c|c|c|c|c|c|c|}
\hline \multirow[b]{2}{*}{ Plankton } & \multicolumn{7}{|c|}{ Macrozoobenthos (PCl) } & \multicolumn{5}{|c|}{ Macrozoobenthos (PC2) } \\
\hline & $-2^{1 / 2}$ & $-11 / 2$ & $-1 / 2$ & $+1 / 2$ & $+1 \frac{1 / 2}{2}$ & $+2 \frac{1}{2}$ & $-21 / 2$ & $-11 / 2$ & $-1 / 2$ & $+1 / 2$ & $+1 \frac{1 / 2}{2}$ & $+2 \frac{1}{2}$ \\
\hline $\mathrm{PCl}$ & -0.22 & -0.27 & -0.41 & -0.49 & -0.59 & -0.63 & 0.35 & 0.32 & 0.16 & 0.33 & 0.34 & 0.26 \\
\hline PC2 & 0.76 & 0.80 & 0.70 & 0.65 & 0.60 & 0.51 & -0.37 & -0.24 & -0.02 & 0.22 & 0.34 & 0.54 \\
\hline
\end{tabular}

\begin{tabular}{|c|c|c|c|c|c|c|c|c|c|c|}
\hline \multirow[b]{2}{*}{ Benthos } & \multicolumn{5}{|c|}{ Estuarine birds (PCl) } & \multicolumn{5}{|c|}{ Estuarine birds (PC2) } \\
\hline & -2 & -1 & 0 & +1 & +2 & -2 & -1 & 0 & +1 & +2 \\
\hline PCl 1 & -0.28 & -0.23 & -0.23 & -0.34 & -0.30 & 0.76 & 0.80 & 0.81 & 0.78 & 0.71 \\
\hline $\mathrm{PC} 2$ & -0.48 & -0.59 & -0.49 & -0.74 & -0.66 & 0.18 & -0.23 & 0.52 & 0.47 & 0.57 \\
\hline
\end{tabular}

Shown are the relationships between standardized concentrations of dissolved inorganic nitrogen (DIN) and phosphorus (DIP) at the start of the spring bloom, the first two principal components of yearly sums of six phytoplankton groups, of the biomass of eight macrozoobenthos species on the tidal flats, and of the biomass of 14 estuarine bird species. The time lag (in years) between the time series is indicated above the columns. Significant correlations are italicized (without correction for multiple comparisons) and printed in bold (if still significant after Bonferroni-correction).

advancement of predation by shrimp on bivalve post-larvae (Philippart and others 2003; Beukema and Dekker 2005). Large and co-varying fluctuations in bivalve recruit densities largely determine the year-to-year variation in the size of the adult stocks (for example, Beukema and others 2001; van der Meer and others 2001). This means that if nutrient loads limit the potential size of the bivalve stock within this system (Brinkman and Smaal 2003), recruitment success determines the extent to which this stock can be actually realized. In the Wadden Sea, a series of mild winters (1988-1990) led to a prolonged period of low bivalve recruitment, and years with recruitment failure were 

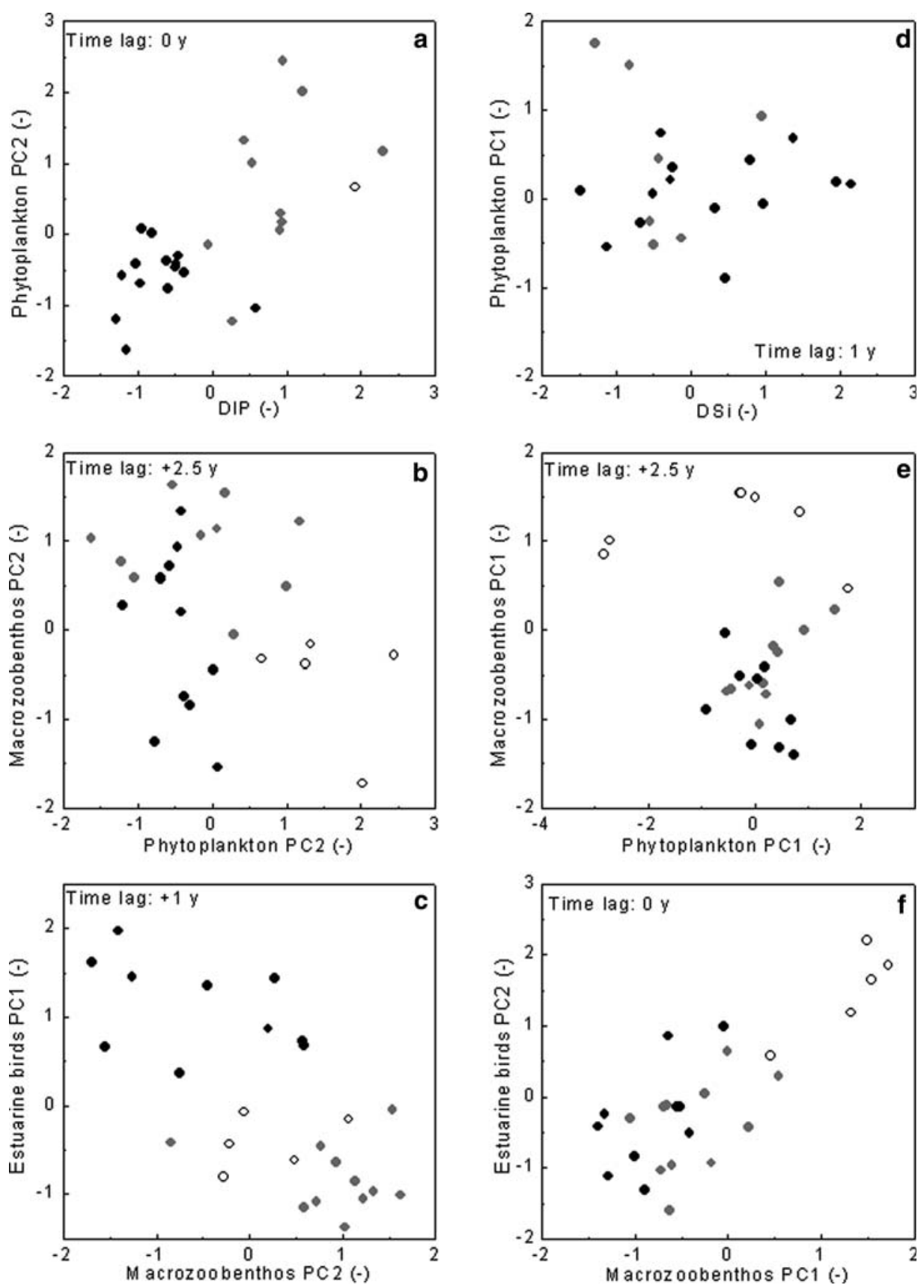

Figure 16. Relationships between limiting nutrients and indices of community structure. a Relationship between standardized DIP concentration (-) at onset of spring bloom and phytoplankton species composition $(P C 2)$ in the same year. b Relationship between species composition of phytoplankton $(P C 2)$ and macrozoobenthos $(P C 2)$ after $2 \frac{1}{2} 2$ years. c Relationship between species composition of macrozoobenthos (PC2) and estuarine birds (PC1) 1 year later. d Relationship between standardized DSi concentration (-) at onset of spring bloom and phytoplankton species composition (PCl) 1 year later. e Relationship between species composition of phytoplankton (PC1) and macrozoobenthos (PC1) after 21/2 years. f Relationship between species composition of macrozoobenthos (PC1) and estuarine birds (PC2) in the same year. Open dots indicate first trophic period (1970-1977 for nutrients and phytoplankton, 1970-1980 for macrozoobenthos and birds), grey dots indicate second trophic period (1977-1987 and 1981-1990, respectively), and black dots indicate third trophic period (1988-2003 and 1991-2003, respectively). 
more frequent during the last approximately 15 years than before (Beukema and Dekker 2005). Temperature-related lowering of recruitment success since 1988 may, therefore, have acted synergistically with the effects of nutrient reduction on marine bivalves in the western Wadden Sea.

Climate Variability. Remarkably, part of the changes in the Wadden Sea as presented here coincided with shifts in marine systems observed at a much larger scale such as the North Sea (Weijerman and others 2005) and the western English Channel (Southward and others 2005). Changes in salinity and possibly weather preceded the shifts in biological variables in 1979. Weather and, most specifically, temperature were likely triggers for the 1988 shift. We can only speculate how these largescale variations may have contributed to the local changes in the Wadden Sea. Variations in precipitation will have affected the European river run off and subsequently influenced the supply of freshwater and riverine nutrients to estuarine areas like the Wadden Sea. If the strength of the local import of organic matter from the sea is also influenced by coastal circulation and river runoff, large-scale changes in circulation and precipitation patterns may have been reflected in local phytoplankton dynamics and subsequent higher trophic levels. Variations in winter temperatures may have affected the biogeographic distributions (and subsequently the local densities) of marine organisms, as has been observed for bird species along the east coast of the USA (Valiela and Bowen 2003).

\section{Conclusions and Implications}

The significant relationships between phosphorus and community structures of phytoplankton, macrozoobenthos and estuarine birds may be spurious, that is, due to other factors than included in the analysis. However, because phosphorus and silicon were limiting at the start of the spring bloom, changes in their concentrations must have affected local primary producers and, hence, most likely, also higher trophic levels. Due to the complexity of the dose-response relationships, the lack of data on some ecosystem components (for example, microphytobenthos biomass and production), the possible role of top-down controls and the concurrence of other structuring factors possibly acting at a larger scale, we cannot conclusively determine if, and if so to what extent, nutrient enrichment and subsequent reduction contributed to the observed trends in the studied communities. Based on the correlation structure within our data set, it appears likely that part of the variance in the studied coastal communities is related to changes in nutrient loads.

This case study demonstrates that policies aimed at bird conservation, fishery management and nutrient reduction should not ignore the possible consequences of measures targeting one of these approaches on other ecosystem components via trophic relationships. Furthermore, our findings reveal that the precise responses of biomass and production to changes in nutrient loads is largely unpredictable, and that chlorophyll- $a$ concentrations and macrozoobenthos biomass are therefore not suited as sole indicators of the trophic status of marine coastal waters. During the past three decades, the control of eutrophication has become a focal point of estuarine and coastal science and management. At present, we are faced with the challenge of understanding the ultimate consequences of nutrient reduction in relation to concurrent effects of other stressors such as exploitation of marine living resources, climate variability and climate change.

\section{ACKNOWLEDGEMENTS}

We thank Jan Hegeman, Wim de Bruin, Dennis Waasdorp and Jaap Zuidewind and numerous volunteers for their help in collecting long-term field data, the Dutch Ministry of Transport, Public Works and Water Management (RWS-RIKZ) for supplying their nutrient data, the Dutch Centre for Field Ornithology (SOVON) for supply of the bird data, and Hanneke Baretta-Bekker, Bert Brinkman, Bruno Ens, Eric Epping, Carlo Heip, Jef Huisman, Scott Nixon, Theo Prins, Wim Wolff, and three anonymous referees for comments on earlier versions of the manuscript. Funding for this study was provided by research grants from the Netherlands Organisation for Scientific Research (Priority Program on Sustainable Use and Conservation of Living Marine Resources), the Netherlands Bremen Oceanography (NEBROC), Dutch Ministry of Transport, Public Works and Water Management (RWS-RIKZ), and by the Dutch Ministry of Agriculture, Nature and Food Quality (LNV).

\section{REFERENCES}

Bakker C, Herman PMJ, Vink M. 1994. A new trend in the development of the phytoplankton in the Oosterschelde (SW Netherlands) during and after the construction of a stormsurge barrier. Hydrobiologia 283:79-100.

Beman JM, Arrigo K, Matson PA. 2005. Agricultural runoff fuels large phytoplankton blooms in vulnerable areas of the ocean. Nature 434:211-4. 
Beukema JJ, Cadée GC. 1996. Consequences of the sudden removal of nearly all mussels and cockles from the Dutch Wadden Sea. PSZNI Mar Ecol 17:279-89.

Beukema JJ, Cadée GC, Dekker R. 2002. Zoobenthic biomass limited by phytoplankton abundance: evidence from parallel changes in two long-term data series in the Wadden Sea. J Sea Res 48:111-25.

Beukema JJ, Dekker R. 2005. Decline of recruitment success in cockles and other bivalves in the Wadden Sea: possible role of climate change, predation on postlarvae and fisheries. Mar Ecol Prog Ser 287:149-67.

Beukema JJ, Dekker R, Essink K, Michaelis H. 2001. Synchronized reproductive success of the main bivalve species in the Wadden Sea: causes and consequences. Mar Ecol Prog Ser 211:143-53.

van Beusekom JEE. 2005. A historic perspective on Wadden Sea eutrophication. Helgoland Mar Res 59:45-54.

Boesch DF. 2002. Challenges and opportunities for science in reducing nutrient over-enrichment of coastal ecosystems. Estuaries 25:744-58.

Brinkman AG, Smaal AC. 2003. Onttrekking en natuurlijke productie van schelpdieren in de Nederlandse Waddenzee in de periode 1976-1999. Alterra Report 888, Alterra, Wageningen.

Bult TP, van Stralen MR, Brummelhuis E, de Baars D. 2003. Mosselvisserij en kweek in het sublittoraal van de Waddenzee. Yerseke: RIVO Report C041/04, RIVO.

Cadée GC. 1984. Has input of organic matter increased during the last decades? In: The role of organic matter in the Wadden Sea. Neth Inst Sea Res Publ Ser 10:71-82.

Cadée GC, Hegeman J. 1974. Primary production of phytoplankton in the Dutch Wadden Sea. Neth J Sea Res 8:240-59.

Cadée GC, Hegeman J. 2002. Phytoplankton in the Marsdiep at the end of the 20th century; 30 years monitoring biomass, primary production, and Phaeocystis blooms. J Sea Res 48:97110.

Camphuysen CJ, Ens BJ, Heg D, Hulscher JB, van der Meer J, Smit CJ. 1996. Oystercatcher Haematopus ostralegus winter mortality in the Netherlands: the effect of severe weather and food supply. Ardea 84A:469-92.

Camphuysen CJ, Berrevoets CM, Cremers HJWM, Dekinga A, Dekker R, Ens BJ, van der Have TM, Kats RKH, Kuiken T, Leopold MF, van der Meer J, Piersma T. 2002. Mass mortality of common eiders Somateria mollissima in the Dutch Wadden Sea, winter 1999/2000: starvation in a commercially exploited wetland of international importance. Biol Conserv 106:303-17.

Cloern JE. 2001. Our evolving conceptual model of the coastal eutrophication problem. Mar Ecol Prog Ser 210:223-53.

Del Hoyo J, Elliott A., Sargatal J. 1992. Handbook of birds of the world, vol 1. Barcelona: Lynx Edicions Barcelona. 696 p.

Del Hoyo J, Elliott A, Sargatal J. 1996. Handbook of birds of the world, vol 2. Barcelona: Lynx Edicions Barcelona. 638 p.

Dodds WK. 2003. Misuse of inorganic N and soluble reactive $\mathrm{P}$ concentrations to indicate nutrient status of surface waters. J North Am Benthol Soc 22:171-81.

Dronkers J. 1986. Tidal asymmetry and estuarine morphology. Neth J Sea Res 20:117-31.

Dronkers J. 2005. Natural and human impacts on sedimentation in the Wadden Sea: an analysis of historical data. The Hague: Report National Institute for Coastal and Marine Management. $47 \mathrm{p}$.

Ens BJ, Smaal AC, de Vlas J. 2004. The effects of shellfish fishery on the ecosystems of the Dutch Wadden Sea and Oostersc- helde. Wageningen: Alterra-rapport 1011, RIVO-rapport C056/04, RIKZ-rapport RKZ/2004.031. 212 p.

Foster-Smith BL. 1976. Pressure generated by the pumping mechanism of some ciliary feeders. J Exp Mar Biol Ecol 25:199-206.

Garamszegi LZ.. 2006. Comparing effect sizes across variables: generalization without the need for Bonferroni correction. Behav Ecol 17:682-7.

Goss-Custard JD, Caldow RWG, Clarke RT, Le V. dit Durell SEA, Urfi J, West AD. 1995. Consequences of habitat loss and change to populations of wintering migratory birds-predicting the local and global effects from studies of individuals. Ibis 137:S56-66.

Goss-Custard JD, Stillman RA, West AD, Caldow RWG, McGrorty S. 2002. Carrying capacity in overwintering migratory birds. Biol Conserv 105:27-41.

Grover JP. 1997. Resource competition. London: Chapman and Hall, 342.

Hastie TJ, Tibshirani RJ. 1990. Generalized additive models. London: Chapman and Hall. 335 p.

Herman PMJ, Middelburg JJ, van de Koppel J, Heip CHR. 1999. Ecology of estuarine macrobenthos. Adv Ecol Res 29:195-240.

Højerslev NK. 1978. Daylight measurements appropriate for photosynthetic studies in natural seawaters. J Cons Int Explor Mer 38:131-46.

Howarth RW, Marino R. 2006. Nitrogen as the limiting nutrient for eutrophication in coastal marine ecosystems: evolving views over three decades. Limnol Oceanogr 51:364-76.

Jeppesen E, Søndergaard M, Jensen JP, Mortensen E, Hansen AM, Jørgensen T. 1998. Cascading trophic interactions from fish to bacteria and nutrients after reduced sewage loading: an 18-year study of a shallow hypertrophic lake. Ecosystems 1:250-67.

Kirk JTO. 1996. Light and photosynthesis in aquatic ecosystems. 2 ed. Cambridge: Cambridge University Press, 401.

Kooijman SALM. 2000. Dynamic energy and mass budgets in biological systems. 2 ed. Cambridge: Cambridge University Press, 424.

Leopold MF, Smit CJ, Goedhart PW, van Roomen M, van Winden E, van Turnhout C. 2004. EVA II Deelproject C2: Langjarige trends in aantallen wadvogels, in relatie tot de kokkelvisserij en het gevoerde beleid in deze. Wageningen: Alterra Report 954, Alterra.

McCullagh P, Nelder JA. 1989. Generalized linear models. 2 ed. London: Chapman and Hall, 511.

van der Meer J, Beukema JJ, Dekker R. 2001. Long-term variability in secondary production of an intertidal bivalve population is primarily a matter of recruitment variability. J Anim Ecol 70:159-69.

Micheli F, Halpern BS. 2005. Low functional redundancy in coastal marine assemblages. Ecol Lett 8:391-400.

Møhlenberg E, Riisgård HU. 1979. Filtration rate, using a new indirect technique, in thirteen species of suspension-feeding bivalves. Mar Biol 54:143-7.

Nakagawa S. 2004. A farewell to Bonferroni: the problems of low statistical power and publication bias. Behav Ecol 15:1044-5.

National Research Council. 2000. Clean coastal waters: understanding and reducing the effects of nutrient pollution. Washington DC: National Academies Press.

Nixon SW. 1995. Coastal marine eutrophication: a definition, social causes, and future concerns. Ophelia 41:199-219. 
Pearson TH, Rosenberg R. 1987. Feast and famine: structuring factors in marine benthic communities. In: Gee JHR, Giller PS, Eds. The 27th Symposium of the British Ecological Society, Aberystwyth 1986. Oxford: Blackwell. pp. 373-95.

Peeters JCH, Peperzak L. 1990. Nutrient limitation in the North Sea: a bioassay approach. Neth J Sea Res 26:61-73.

Philippart CJM, van Aken HM, Beukema JJ, Bos OG, Cadée GC, Dekker R. 2003. Climate-related changes in recruitment of the bivalve Macoma balthica. Limnol Oceanogr 48:2171-85.

Philippart CJM, Dijkema KS, van der Meer J. 1992. Wadden Sea seagrasses: where and why? Neth Inst Sea Res Publ Ser 20:177-91.

Philippart CJM, Cadée GC, van Raaphorst W, Riegman R. 2000. Long-term phytoplankton-nutrient interactions in a shallow coastal sea: algal community structure, nutrient budgets, and denitrification potential. Limnol Oceanogr 45:131-44.

Piersma T, Koolhaas A, Dekinga A, Beukema JJ, Dekker R. Essink K. 2001. Long-term indirect effects of mechanical cockle-dredging on intertidal bivalve stocks in the Wadden Sea. J Appl Ecol 38:976-90.

Postma H. 1961. Transport and accumulation of suspended matter in the Dutch Wadden Sea. Neth J Sea Res 1:14890.

van Raaphorst W, de Jonge VN. 2004. Reconstruction of the total $\mathrm{N}$ and $\mathrm{P}$ inputs from the IJsselmeer into the western Wadden Sea between 1935-1998. J Sea Res 51:109-31.

Ridderinkhof H, Zimmerman JFT, Philippart ME. 1990. Tidal exchange between the North Sea and Dutch Wadden Sea and mixing time scales of the tidal basins. Neth J Sea Res 25:331-50.

Riegman R, Kuipers BR, Noordeloos AAM, Witte HJ. 1993. Sizedifferential control of phytoplankton and the structure of plankton communities. Neth J Sea Res 31:255-65.

Riisgård HU, Møhlenberg F. 1979. An improved automatic recording apparatus for determining the filtration rate of $M y$ tilus edulis as a function of size and algal concentration. Mar Biol 52:61-7.

Riisgård HU, Seerup DF. 2003. Filtration rates in the soft clam Mya arenaria: effects of temperature and body size. Sarsia 88:415-28.

Riisgaard HU, Seerup DF, Jensen MH, Glob E, Larsen PS. 2004. Grazing impact of filter-feeding zoobenthos in a Danish fjord. J Exp Mar Biol Ecol 307:261-71.

Roelke DL, Eldridge PM, Cifuentes LA. 1999. A model of phytoplankton competition for limiting and nonlimiting nutrients: Implications for development of estuarine and nearshore management schemes. Estuaries 22:92-104.

van Roomen $M$, van Turnhout C, van Winden E, Koks B, Goedhart P, Leopold M, Smit C. 2005. Trends van benthivore watervogels in de Nederlandse Waddenzee 1975-2002. Limosa 78:21-38.

Rosenberg R. 1985. Eutrophication-the future marine coastal nuisance?. Mar Pollut Bull 16:227-31.

Rossi F, Herman PMJ, Middelburg JJ. 2004. Interspecific and intraspecific variation of $\delta^{13} \mathrm{C}$ and $\delta^{15} \mathrm{~N}$ in deposit- and sus- pension-feeding bivalves Macoma balthica and Cerastoderma edule: evidence of ontogenetic changes in feeding mode of Macoma balthica. Limnol Oceanogr 49:408-14.

Rumohr H, Brey T, Ankar S. 1987. A compilation of biometric conversion factors for benthic invertebrates of the Baltic Sea. Baltic Mar Biol 9:1-56.

Schindler DW. 2006. Recent advances in the understanding and management of eutrophication. Limnol Oceanogr 51:356-63.

Smith VH. 2006. Responses of estuarine and coastal marine phytoplankton to nitrogen and phosphorus enrichment. Limnol Oceanogr 51:377-84.

Sommer U. 1984. The paradox of the plankton: fluctuations of phosphorus availability maintain diversity in flow-through cultures. Limnol Oceanogr 29:633-6.

Southward AJ, Langmead O, Hardman-Mountford NJ, Aiken J, Boalch GT, Dando PR, Genner MJ, Joint I, Kendall MA, Halliday NC, Harris RP, Leaper R, Mieskowska N, Pingree RD, Richardson AJ, Sims DW, Smith T, Walne AW, Hawkins SJ. 2005. Long-term Oceanographic and Ecological Research in the Western English Channel. Adv Mar Biol 47:1-105.

Stolte W, McCollin T, Noordeloos AAM, Riegman R. 1994. Effect of nitrogen source on the size distribution within marine phytoplankton populations. J Exp Mar Biol Ecol 184:83-97.

Thingstad TF, Sakshaug E. 1990. Control of phytoplankton growth in nutrient recycling ecosystems. Theory and terminology. Mar Ecol Prog Ser 63:261-72.

Underhill LG, Prŷs-Jones RP. 1994. Index numbers for waterbird populations. (I) Review and methodology. J Appl Ecol 31:463-80.

Valiela I, Bowen JL. 2003. Shifts in winter distribution in birds: effects of global warming and local habitat change. Ambio 32:476-80.

Weijerman M, Lindeboom H, Zuur AF. 2005. Regime shifts of the marine ecosystems of the North Sea and Wadden Sea. Mar Ecol Prog Ser 298:21-39.

West AD, Goss-Custard JD, Le dit Durell V. SEA, Stillman RA. 2005. Maintaining estuary quality for shorebirds: towards simple guidelines. Biol Conserv 123:211-224.

Wetsteyn LPMJ, Duin RNM, Kromkamp JC, Latuhinin MJ, Pouwer A, Prins TC. 2003. Verkenning Draagkracht Oosterschelde. Yerseke: report RIKZ/2003.049, RIKZ.

Zwarts L. 1991. Seasonal variation in body weight of the bivalves Macoma balthica, Scrobicularia plana, Mya arenaria and Cerastoderma edule in the Dutch Wadden Sea. Neth J Sea Res 28:23145.

Zwarts L, Wanink JH. 1989. Siphon size and burying depth in deposit- and suspension feeding benthic bivalves. Mar Biol 100:227-40.

Zwarts L, Wanink JH. 1993. How the food supply harvestable by waders in the Wadden Sea depends on the variation in energy density, body weight, biomass, burying depth and behaviour of tidal-flat invertebrates. Neth J Sea Res 31:441-476. 